\title{
التعددية الثقافية في القرن الحادي والعشرين
}

\section{اقبال شوفي ابراهيم}

\section{مقدمة}

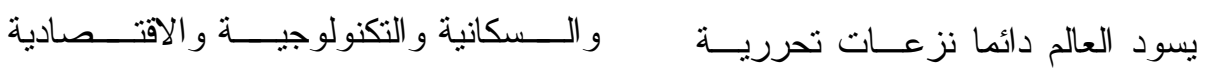

منصلة بكل جزئيات العالم المتمنل في البلدان و الثقافية.

وظهرت جهود المنظمات الدولية التي

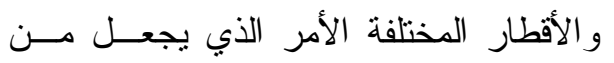

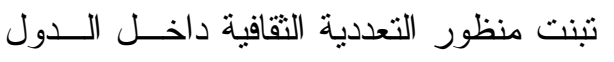

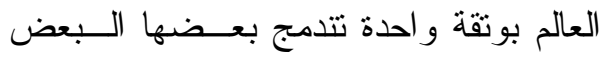

و المجتمعات للوصول بنلاك المجتمعات إلــي لبعي

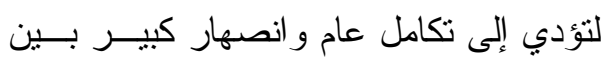

أفضل الأطر و النماذج التي توضتح الــرو ابط لتصات

الثقافات و الثعوب المختلفة الأمر الذي يجعل عالمان

و العلاقات التي تجمع التتوعات الثقافية داخل العالم كله قرية صغيرة تجمعها رو ابط و احدة إطار الدولة مما أدي إلي الاهتمــام الــدولي وعلاقات مشتركة وذلك من أجل جعل العالم

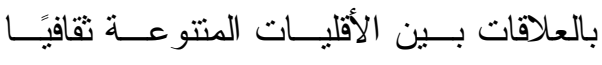
كله ذو فهم مشترك و علاقات و احدة مما يفتح

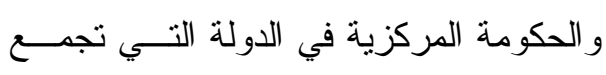

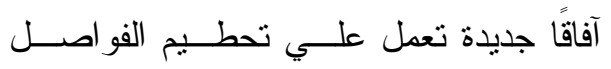

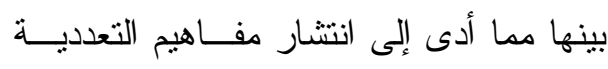

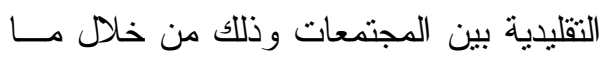

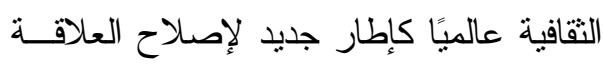
شهدته الكرة الأرضية في الأربغــين عامَّـا

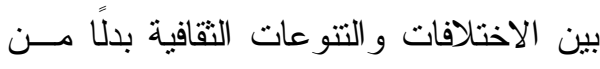

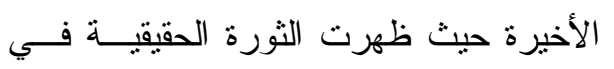

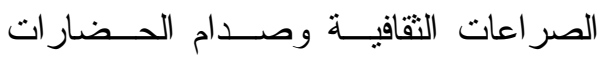

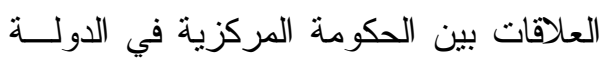

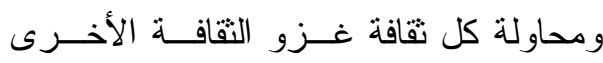

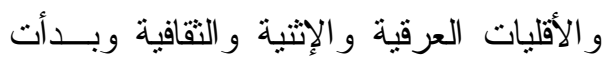
و القضاء عليها. (')

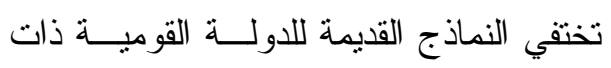
ويمكن التفريق بين مستوبين لمفـــاهيم النسيج المنمانل و المنسجم لتحل محلها نماذج

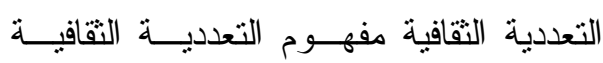
من التعددية التقافية داخل الدولـــة تجمعهـــا العالمية ومفهوم التعددية الثقافيــة القانونيـــة

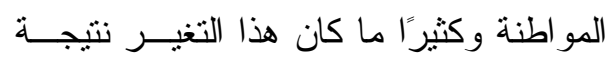

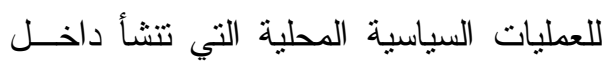
المجتمع الأمر الذي انتهى إلــي أن النمــاذج (1) بريان باري، الثقافة و المساواة نقد مساواتي القديمة لم تعد تتتاسب مع الظروف التاريخية

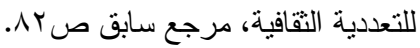


إليها جميع الدول فإن المستوى الثاني يحنوي

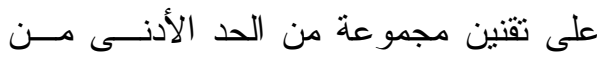

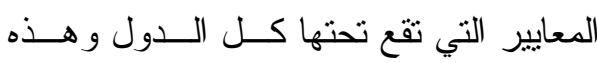
العمليات المزدوجة لانتشار مفاهيم التعدديــة

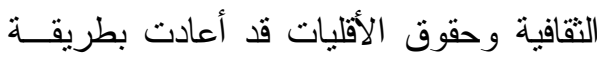
أساسية تشكيل التصور ات و المفاهيم التقليدية

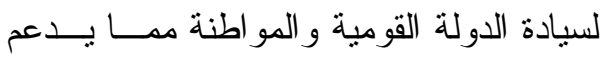

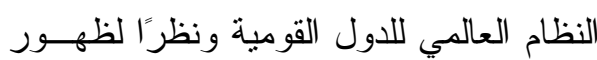
مفهوم القرية الكونية وسهولة الانتقال للأفراد و السلع و الخدمات بين الدول وزو ال القيـــود و الحدود فان حركة الأفر اد الإنــسانية بـين ولين الدول لأغر اض السياحة و العمل و الدر اسة قد الداته

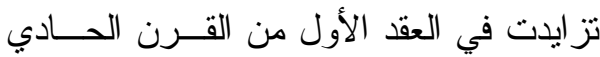
و العشرين مما أدى إلى أن يعيش أفر اد مــن فئن ثقافات مختلفة فترات طويلة من الزمن داخل ثقافة أخرى ويمارسون مظاهر حياتية متعددة الثقافات ويو اجهون مظاهر ومقومات الثقافة التي انتقلو ا إليها ويعيشون فيها بما لديهم من مظاهر ومقومات نقافية من ثقــافتهم التــي بــي جاءوا منها مما أدى إلى ظهور قدرًا ملحوظًا

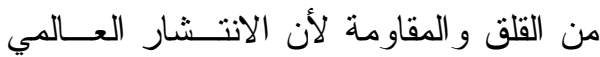

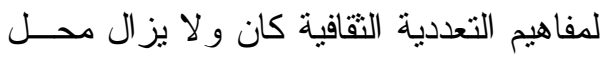

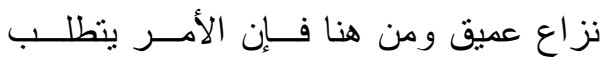
توضيحًا للهرف من نشر مفــاهيم التعدديـــة

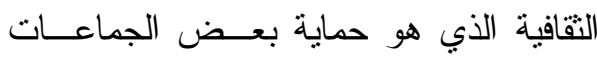
الضعيفة في العالم الحديث من الظلم الجسيم الذي يحيق بها حيث نجد أن الخطط التتموية
حيث تتلخص مفاهيم التعددية التقافية العالمية في مجموعة الأفكار المنتشرة حول أهميـــة التكيف مع الاختلاف و التتوع و التي تتاولتها شبكات دولية غير حكومية وعلماء وباحثون

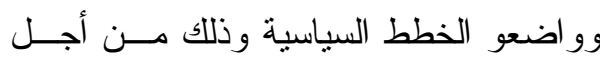

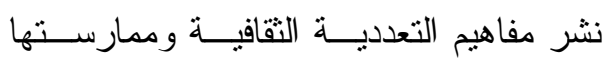
وكذلك معرفة أفضل الممارسات في البلـــــان المختلفة وبنـــاء شـبكات تتجــــاوز الحــدود

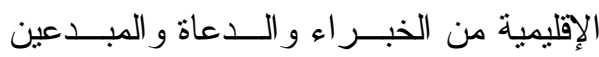
وخلق مناطق آمنة للحديث في موضـــوعات

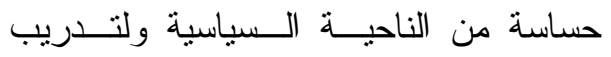
المربين المحليين و البيروقر اطيين و المنظمات غير الحكومية و العاملين في أجهزة الإعــلام

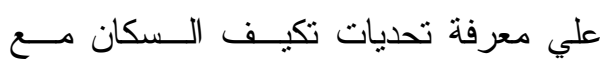
التعددية الثقافية ومع التعدد العرقي. (') أما من ناحية التعددية الثقافية القانونية فإن هناك تقنين لمفاهيم التعددية الثقافية فـي تئي مجمو عة من القو اعد الدولية القانونية أو شبه

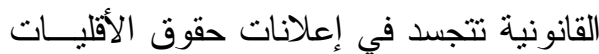
وتتمية المعايير الدولية لحقوق الأقليات علي إعلينات الصعيدين الكوني و المحلي. وعلى هذا فإذا كان المسستوى الأول

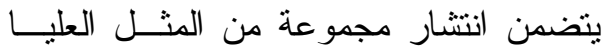

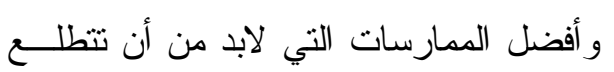

(1) بريان باري، الثقافة والمساواة نقد مساو اتي

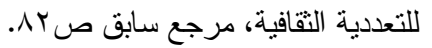


الثقافية الليبر الية يسهل تبينها من قبل أنظمــة

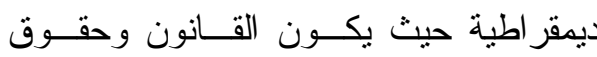
الإنسان مصونين.

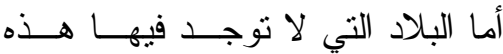

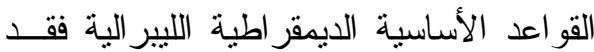
تكون في حاجة إلي تو افر مستوى معين من

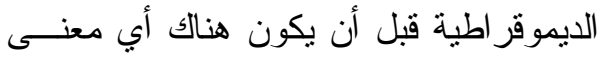
للدفع نحو التطبيق الثامل لمفاهيم التعدديــة الثقافية لذلك فإن مشكلة الـصر اع العرقـي لـي

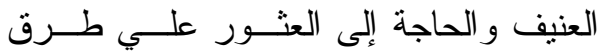
للتعايش العرقي غالبًا ما تكونان أكثر ضراوة في البلدان ذات الديموقر اطيات الضعيفة. ولقد تتاولت المنظمات الدولية هــذين المنظورين أحيانًا بإقرار ها أعلــى المعـايير

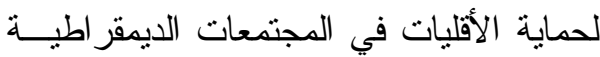

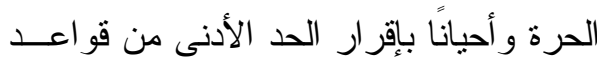
التعايش العرقي التي يمكن أن نتوقعها في أي

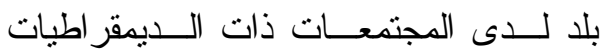
الضعيفة حيث العلاقة بين العدالة و الأمن في

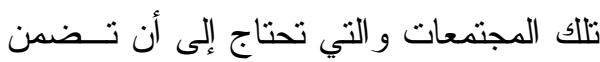
القواعد المعايير الدولية بـصورة مسستقبلية حيث الاعتر فاف بالأقليات العرقية والـسكان لـانيل

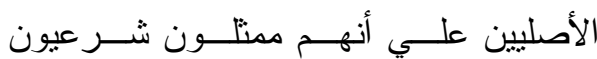
وشركاء متساوون في الحكم في المجتمعات.

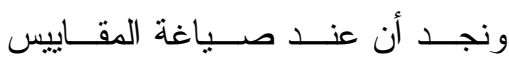

والمعايير للتعددية الثقافية فإن الباب يفتح إما

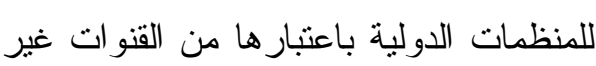

المختلفة توجه نحو التماتل و استبعاد الأفليات

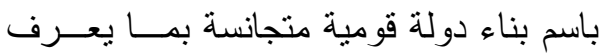

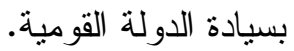
ولذلك نجــــ أن التــصور الجزئسي

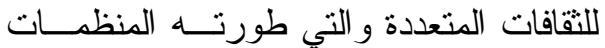
الدولية لمعايير الحقوق الإنسانية هو امتــداد

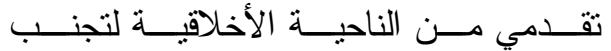
التصور ات القمعية غيــر الليير اليـــة لفكـر لفر التعددية النقافية و أصبحت الخطابات السياسية و المعايير المشرو عة للتعددية الثقافيــة التــي دفع بها القانون الدولي والمنظمات الدوليـــة هو تطور طبيعي ومنطقي لمعـايير حقـوق الإنسان العالمية.

إن وثائق الأمم المتحدة و اضحة فيمـــا يتعلق بمعايير التعددية الثقافية وتتشير موادها

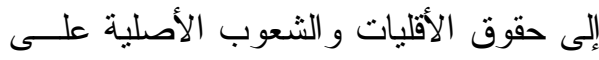

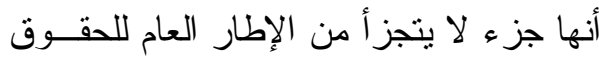

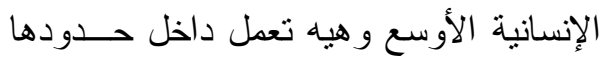
حيث تفهم التعددية النقافية على أنها مفهــوم يرشده ويضبطه الالتز ام الــسياسي بمبــادئ الحرية الفردية و المساو اة. ()

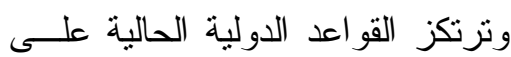

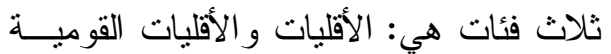
و الثعوب الأصلية ومن البديهي أن التعددية

(1) بريان باري، الثقافة و المساواة نقد مساو تي

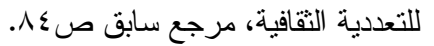


الرئيسي الذي تضطلع فيه الحقوق الفرديـــة في إطار الليبرالية التي تمنل عمــاد ســائر

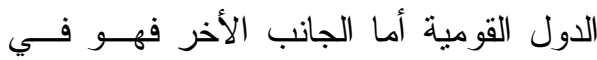
مجال العلوم الاجتماعية ويركز على طبيعــة

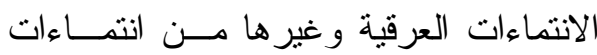
الجماعات الموجودة علي أرض الواقع وعلي السمة الفعلية المميزة للتفاعلات القائمة بـين لـين الجماعات العرقية ومجموعة السياسات التي طورت بهدف استبعاد التنوع الثقافي المتتامي

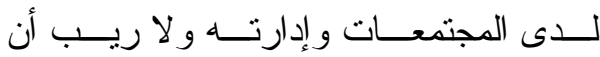
التعددية الثقافية حظيت بدعاية ســلبية فــي ولدي السنو ات الأخيرة حيث امتدت أذرع الهجمات التي شنت عليها بداية من القــرن العــشرين

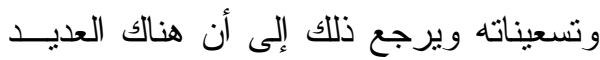
من الهجمات التي وجهت في الأساس إلـى لـى

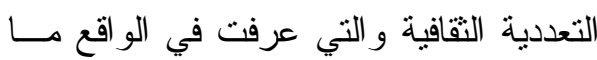

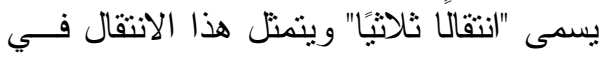
تفكك الدولة القومية أو دفع الأقليات الوطنية

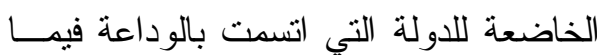
سبق إلى أن وصلت إلى مطالــــب انفــــالية

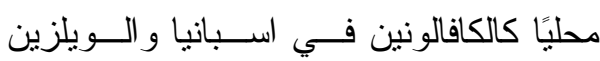
و الاسكتلنديين في بريطانيا و النقيصة الثانيــة

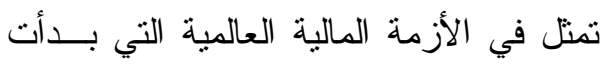

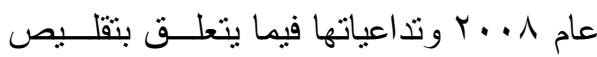
الخدمات العامة وارتفــاع معـدل البطالـــة ومخاوف أكثر لدى الثعوب التي تشعر بعدم الارنياح في ظل دوامة الاختلالات المتز ايدة
الرسمية التي تتنتر بواسطتها أنـــاط مـن

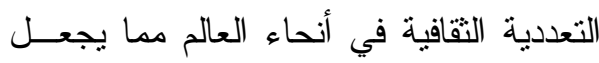
تلك المنظمات الدوليــة كمتحــدث بلــــان المجنمع الدولي الذي يثير المخاطر الأخلاقية

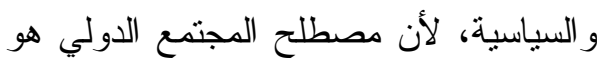

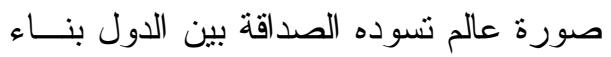

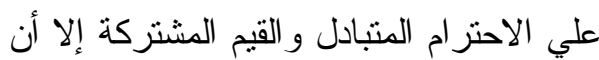
و اقع نظام العالم يتسم بانقسامات ايدولوجيــــة

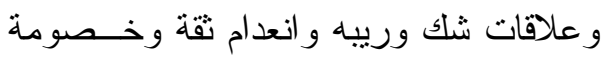

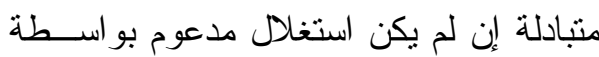

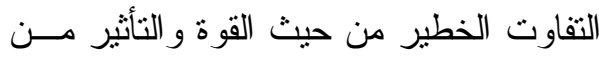
جانب الدول القومية حيث تطبيــق التعدديـــة الثقافية من غير تبني أراء الثعوب الأخرى الأمر الذي يجعل من تلك الممارسات فــــاً استعماريًا جديدًا لا تقبله العديد مـن الــدول لـال

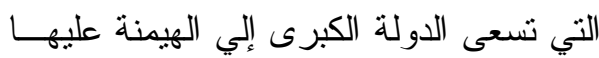
باسم المجتمع الدولي الذي لم ير اعي مصالح

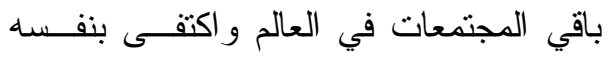
وأمثاله في تطبيث هذه التعددية الثقافية حيث خططه لتتمية وتشجيع التعددية التقافية التـي لهي لهي لا تعكس قيم المجتمع الدولي المتحد كله. و إذا نظرنا إلى التعددية الثقافية عـنـ قـرب نجد أنها تتحصر فما بين النظرية الـسياسية و العلوم الاجتماعية. لذلك نرى أنه من الو اجب التوفيق بين التعددية الثقافية من حيث النظرية الـسياسية وذلك من خلال تأكيدها على الهويات و الدور 
تفتقر إلى التحديــــــــــون صــور أكثــر

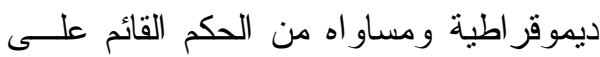

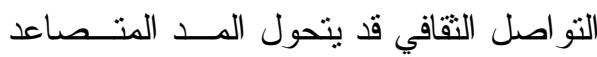
لليمين المتطرف إلي طوفان يمنل عقبة منيعة

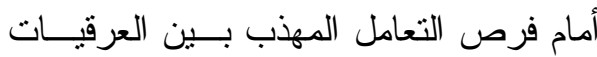

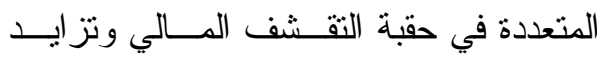
معدلات البطالة و التخفيض الحاد للنفقات في مجال الخدمات العامة التي نقف الآن علـى لـى

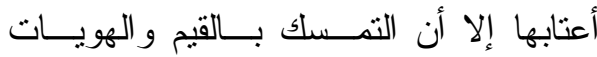

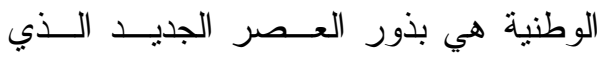

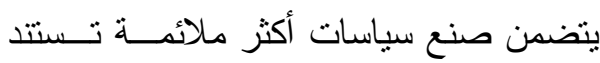

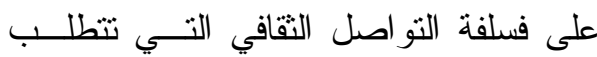
إقامة قدر من الحوار و التفاعل بين العرقيات يفوق ما تطلبه معظم صور التعددية الثقافية. أوثًا: مفهوم التعددية الثقافية

تتعدد مفاهيم التعددية النقافية بـشكل

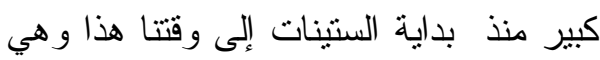
تحمل في طياتها العديد من المفاهيم ولكنتــا

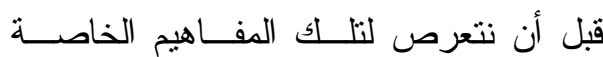
بالتعددية الثقافية يجب أن ننوه عنها تاريخيًا

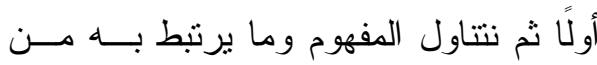
مبادئ التعددية الثقافية وسياستها ومفهومهــا ما بين العنصرية وحقوق الإنسان. نبذة تاريخية عن التعددية الثقافية: لقد ظهرت التعدديــة الثقافيـة فـي الخطابات العامة في أواخر الستينات و أوائل
السرعة الناشئة عن معــدل التغييــر بــالغ

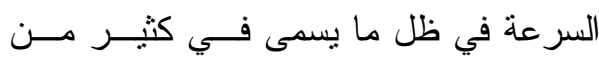
الأحيان بفترة ما بعد الحداثة.(')

أما النقيصة الثالثة فهـي المخــاوف

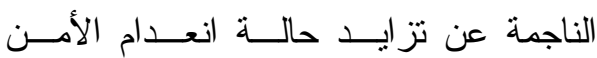

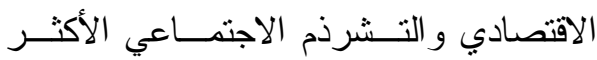
شمول أو الذي القي به على قضايا الهجــرة

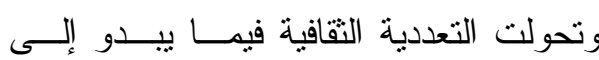
الوعاء الذي تصب فيه الدول مخاوفها و التي تكمن منابعها في أغلب الأحيان من تغييرات اجتماعية و اقتصادية أوسع نطاقًا إلى حد بعيد من التغيرات الناشئة عن الهجرة وسياسـات التعددية النقافية.(؟)

إلا أن التعددية الثقافية تعاني عيوبًا لا لانيا يمكن معالجتها دون الانتقال إلى مرحلة أكثر

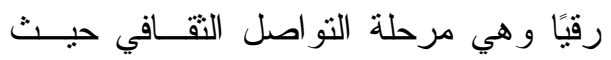
تستتد السياسات الجديدة في كثير من الأحيان إلى نظرية رأس المال الاجتمــاعي وفلــسفة النزعة المجتمعية بالإضافة إلــي المطالبـــة بالو لاء و التمسك بقيم مشتركة وهويات وطنية

(1) B. Barry, culture and equality: An Egalitarian critique of multiculturalism, polity press, 2001, p224.

(2) W. Kymlicka, multi-cultural citizenship; A liberal theory of minority right, oxford university press, 1995, p19. 
كما أن للتعددية الثقافية جانــب بــدعو إلــى تكافؤ الفرص ومناهضية التمبيز الذي غالبًّـا ما تقعله النقاشات المتعلقة بمعنــى التعدديـــة وفاعليتها.

أما في كندا فإن النقاش حول العلاقات المضطربة بين الإقليمين الناطقين بالإنجليزية و الفرنسية في سنينات القرن العـشرين أدى لإلئين إلى تكوين لجنة ملكية أوصت بثنائية اللغـــة

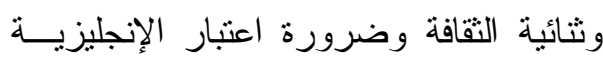
و الفرنسية لغتين رسميتين إلا أن قانون ثثائية الثقافة وثثائية اللغة لعام 1979 أثنار أيــضيًا مسألة الأقليات الأخرى في كندا، واعتمــدت

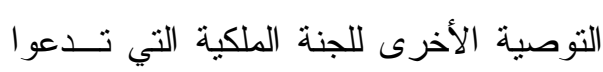
إلى ضرورة توسيع نطاق التعددية التقافيــة في الهوية الكندية كسياسة رسمية وكان هذا نوان مقبولًا في البداية في إطار ثثائي اللغة يثمل

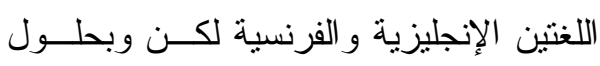

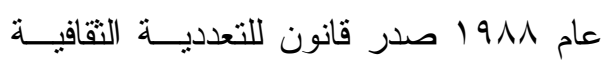
وسع نطاق شروط التضمين.

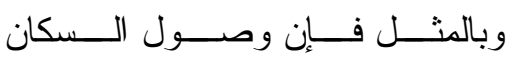

المهاجرين من الهند وباكستان وبــنجاديش وليش

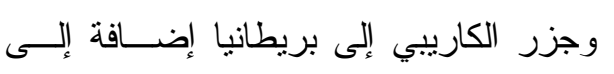

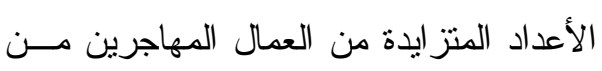

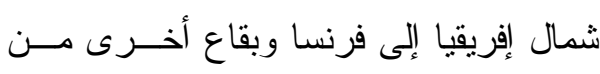

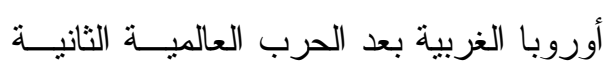

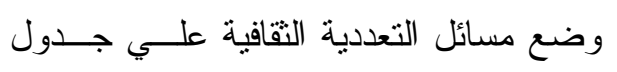
الأعمال العام لتلك البقاع إذ بدأت الجاليــات
السبعينات من القرن العشرين عندما بـــأت كنًا من أستر اليا وكندا في التصريح و السماح بهجرة جديدة راحت تضفي الصبغة الأسيوية على هاتين الأمتني.

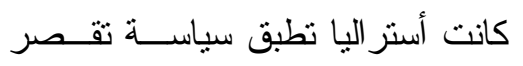

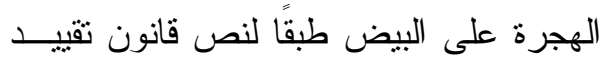

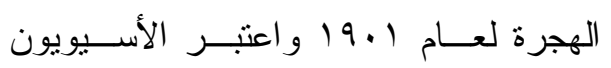

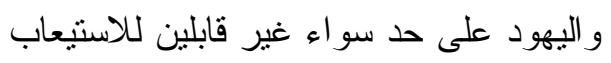

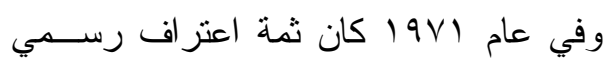

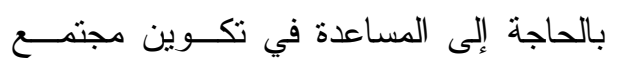

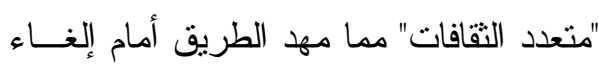

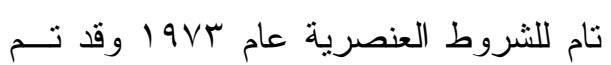

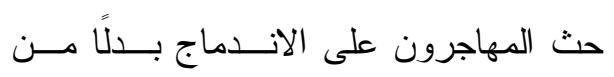
مطالبتهم بالخضوع للاستيعاب أي أنه أصبح

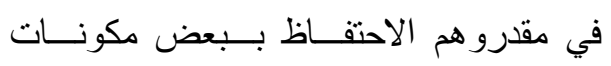
"ثقافتهم الوطنية" و اعتبرت جمعيات الجاليات

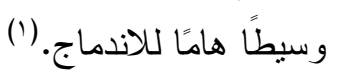
فالتعددية الثقافيــة ضــــت تـشكيل كيانات يشارك فيها المهـــاجرون و الأقليــات العرقية مشاركة منصفة مع الإقرار بمعقولية

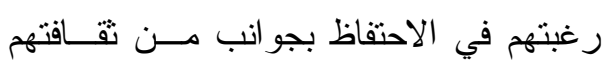

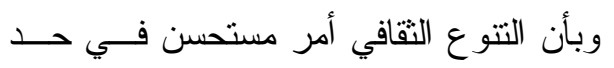

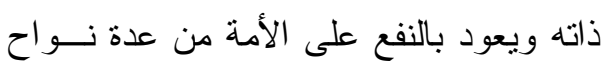

(1)Y. Alilbahai- Brown, After multicultural, foreign policy center 2000, page 201. 
إز اء الملونين و أخبرًا عدم استعداد جاليــات

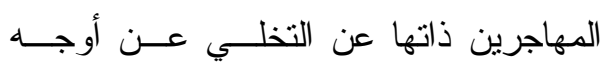

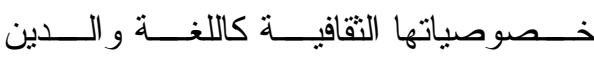
ومضاهات الثعوب المــضيفة فـي جميــع

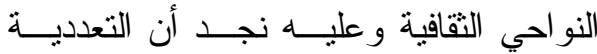
الثقافية لم تدخل قاموس المفردات العسام إلا لإن

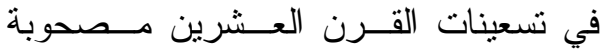

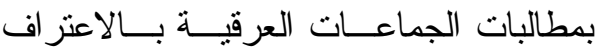

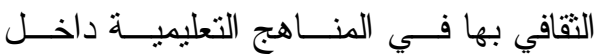
المدارس والجامعات ولذللك كــان المفهــوم

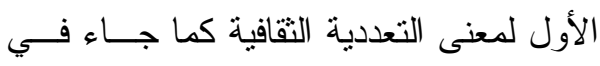
قاموس هارير كولينز لعلم الاجتمــاع فـــي لاوني تسعينات القرن العشرين أن التعددية التقافيـــة هي: إدر الك التعدد الثقافي وتعزيزه فالتعددية الثقافية تحتفي بالتنوع الثقافي وتـسعى إلـى التى

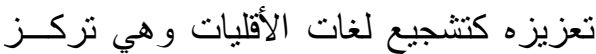
في الوقت ذاته على العلاقة غيــر المتكافئـــة بين الأقلية و الثقافات السائدة. (1) إذن فالتعددية الثقافية عادة ما تـششير إلى السياسات التي تضعها الدول المركزيـــة

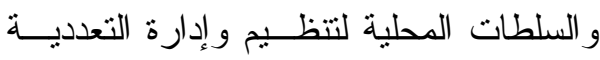

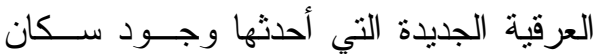

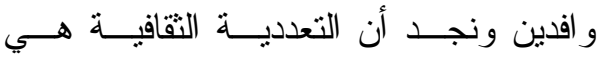

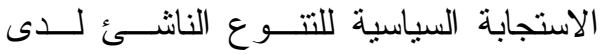
المجتمعات حيث تــزداد التعدديــة الثقافيــة

(1) R. Hosan, multiculturalism: some in convenient truths, politicos press, 2010, p6.
المهاجرين تشكل وجودًا دائمًا أو شبه دائـم وفي حين رفضت فرنسا بصفة خاصــة أي سياسة تمنح المهاجرين الجدد اعتر افًا رسميًا فقد ألقى وزير الخارجية البريطاني بيانًا عام

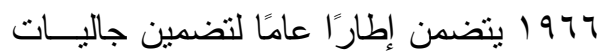
المهاجرين ككل ودمجها في الثقافة و التكوين السياسي القومي لبريطانيا.

\section{مفهوم التعددية الثقافية}

إن التعددية الثقافية تعني في بعـض فضلئ

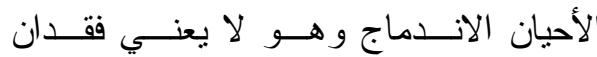
المهاجرين لخصائصهم ونقافتهم الوطنية بــل لــل أنها عملية تسطيحية تهدف إلى التجانس بـلـل إلى التتوع الثقافي الــذي يــــاحبه تـــــافؤ اللفرص في ظل مناخ من التسامح المنبادل. ونجد أحيانًا أن التعددية الثقافية تصبغ لتحن

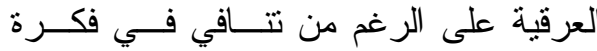
العنصرية مع العصر الحديث إلا أن العــرق لرق لرقي يكون هو السائد في معظم النقانشات الـــائرة

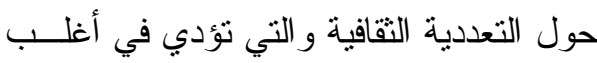

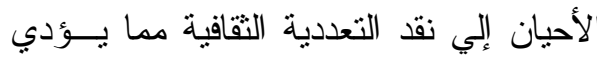

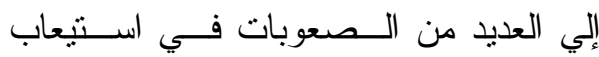
الجاليات الأحدث من ثقافات الدول المــضيفة ويمكن اعتبار هذا الاستيعاب صــعبًا لعـدة العـان أسباب أهمها الخصوصية العرقيـــة و التــي ليكي تتعلق بالاختلافات الفسيولوجية كلون البشرة

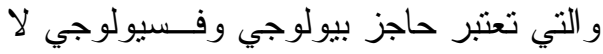

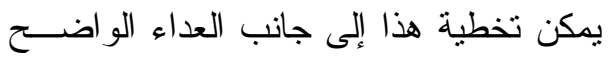
الذى بداه سكان الدول من البيض المضيفون 
الاهتمام بالصدق و الاهتمام بالعدالـــة يأتيـــان

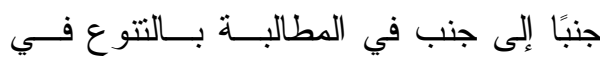

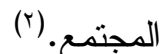

فالتعددية الثقافية هـــي مظهـر مسـن

مظاهر التعدد لألوان من الثقافات المختلفـــة التي تقدمها المجتمعات لإفر ادها و التي تعكس على العلاقات الاجتماعية و الهوية و الانتمـــاء و التقاليد ومحاولة الاستفادة من تلك الثقافــات

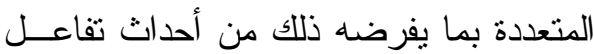
بين الثقافات واحتر ام حقوق الإنسان و إعلاء ثقافة الحوار مع التأكيد على الخصوصية. فأهم ميزة في التعددية هي اخـتلاف الثقافات البشرية وتتوعها فكل مجتمع يتميـز عن غيره بثقافته و التي تشكل قو امًا اجتماعيًا لذا فإن الثقافة تحتل موقعًا أساسيًا في حيــاة المجتمع فهي تمنل طرق و أســاليب الحيــاة ومرجعيتها بمنظومنها القيمية السائدة بمعنى أوسع فإن الثقافة هي حال البشر الذي يتكون

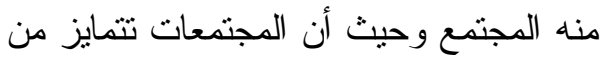
حيث البيئة و التجربة فإن الثقافات تختلف تبعًا

(Y) أومانارين وساندرا هارديغ: نقص المركزية

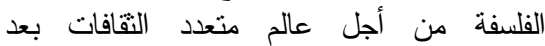

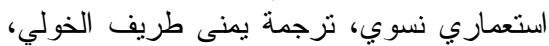

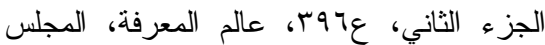

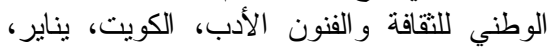

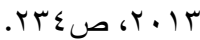

$$
\text { فتزداد (التعددية العرقية) بإطر اد. }
$$

فالتعددية الثقافية هي بمثابة حوار بين

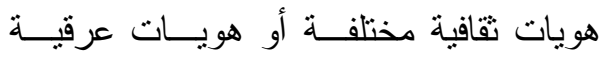
و إهمال الفوارق بين تللك الهويات من أجــل هوبل خلق هوية وووحــدة بهـدف إبــراز التعـدد كمركب أساسي للمجتمع حيث يكون المجتمع

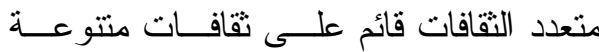
وليس نقافة و احدة عليا ومفضلة ويكون هناك

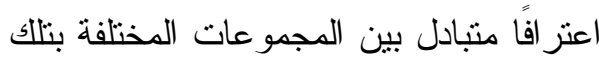
(النقافات. (')

حيــث أن نظــــــة التعدديـــة الثقافيــة وخبرتها يمكنها أن تقـضيا إلـى مجــالات مستجدة ومنتجة لأساليب الحيــاة و البحــث داخل المجتمع الواحد و إلى إيجاد نظريــات جديدة في ساحات قديمة حيث من الممكن أن تؤدي التعددية الثقافية إلى عــالم ومجتمــع

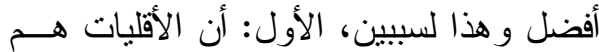
أنفسهم سيصبحو ا هم الأقرب إلــى التعــرف التهـ على الأشياء و الفرضيات الخاطئة و المنحازة، و الثاني: هي أن هذه الأنماط من التغيــرات التي تطر أ على المجتمع وتحذو حذو التعددية النقافية سوف يساعد في كثف النقاب علـى لـى

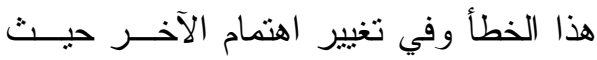

(1) Schon waldee, Germany: integration policy and pluralism in a selfconscious country of migration, Rutledge, 2010, p240. 
وقامت بترقيــة الـــوعي البيئسي و الأنتـــوي وحاولت في بحثها عن تحقيق الذات توســيع

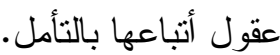

و التعددية الثقافية لغويًا تعني حكم يتم

من خلال عملية أخذ ورد بين فئات منتافسة من مختلف القطاعات أو من الحكومة ذاتها.

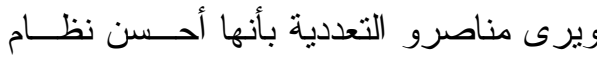
ديموقر اطي في مجتمع معقد إذ أن مسـساهمة

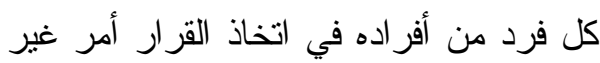
عملي. فقي المجتمع المتعــدد يحـافظ علـى حقوق الفرد بنوع من الموانــع و المــــوازين

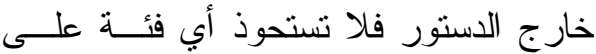

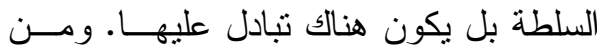
خلال انتماء و انخر اط ونشاط الفرد في إحدى هذه الفئات يمكنه أن يؤثر على اتخاذ القرار.

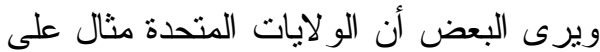

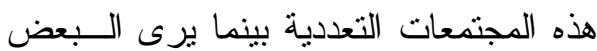

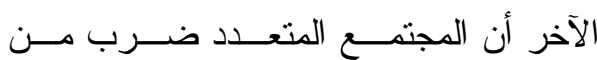
ضروب الخيال وما المجتمع الأمريكي سوى الدع اند

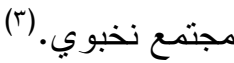

إلا أن الباحثة تعرف التعددية الثقافيــة بأنها تعني وجود ثقافات فرعيــة وتكوينـات إنـات

(r) ناهد محمد عبد المقصود عبد الرازق: التعددية

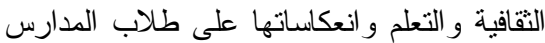

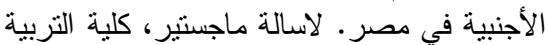

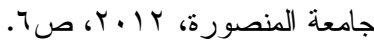

لاختلاف أساليب و أنماط الحياة. (') ولما كان الاختلاف و التعدد سمة مـن

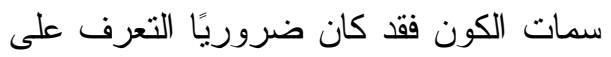
المفاهيم المختلفة للتعددية الثقافية لما له مـنـ لهن

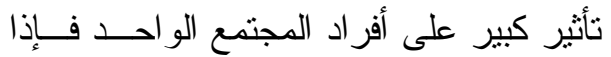
نظرنا إلى المفهوم اللغوي للتعددية النقافيــة نجد أنه اسم مؤنث منسوب إلى تعدد وهــــ يعني التمايز و الاختلاف و التعدد و التقرد من إنى مادة (عدد). أما الثقافة فهي تأتي من المصدر تقف

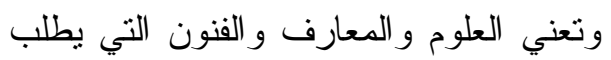
الحذق فيها وهي تعني أيضًا الإحاطة بالعلوم

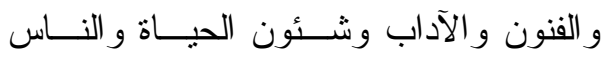
وتعني أيضًا مجمو عة السمات التي توجد في وني زمان ومكان معينين(r). ونجـــــ أن الحركــات الــشبابية فــي الستينات وخاصة اليسار قد عارضت تمــرز

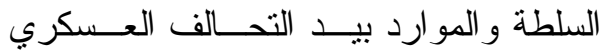
الصناعي وعارضت حرب الفيتتام واعتتقت قضايا عديدة وسعت إلى إقامة نظام اجتماعي

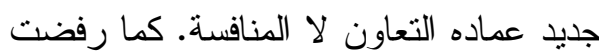
هذه الحركات بـشـدة الأنظمــة الاســتندادية

(1) عمر مصطفى محمد. العولمة النقافية و النقافة السياسية العربية. برنامج الإصلاح الديموقر اطي العي و الثقافة العياسية والتناركية في الوطن العربية العبية

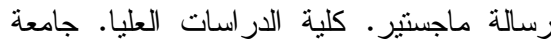

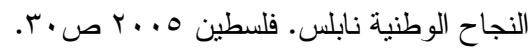

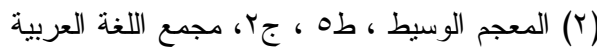

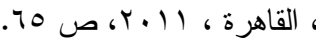


و الو افدين مما أسفر عن تتكل صور منباينة إلى حد ما من التعددية الثقافية مما أدى إلـى لـى لتى توسيع مفاهيمها وفقًا للمناقتات العديدة التـي لئي

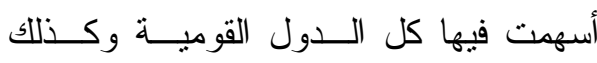

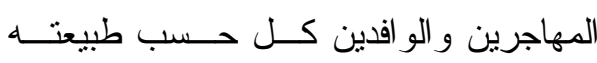
وخصائصه المميزة ومنطلباته البيئية. التعددية ما بين العنصرية وحقوق الإنسان: إن مبدأ المساو اة بين البشر كان غيــر متوفر بعد قيام الحرب العالمية الثانية 19 19 وهنا يمكن رؤية أصول التعدديـــة النقافيــة

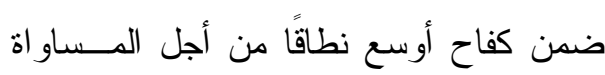
بين البشر عقب نهاية الحرب العالمية الثانية فنجد أن الإعلانات العالمية لحقوق الإنسسان

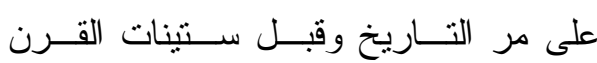

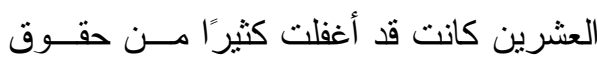

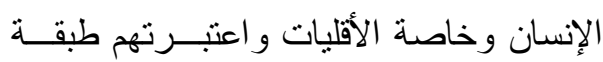
أدنى من البيض ففـي عــام 1919 حينمــا حاولت اليابان إدخال كلمة تتعلق بالمـساو اة

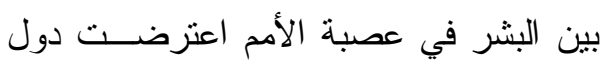
الإمبر اطوريات التي كانــت تحتــلـ الــبلاد الأخرى في آسيا وفي أفريقيا اعتقادًا مــنهم وحرضـا على الإعــلان الرســـي بمبــادئ

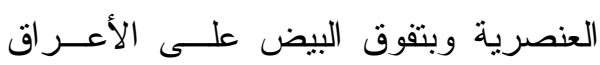
الأخرى ولكن بعد تحرير العديد من الــدول

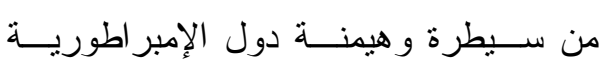
الأوروبية على تلك الدول أسفر فـــي نهايــة الأمر في ســنينات القــرن العـشرين إلــى لــ
تتضمنها الثقافة العامــة للاولـــة أو ثقافـات

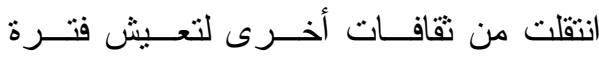

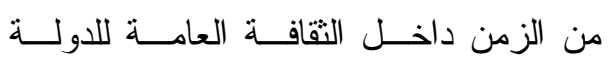
القو مية.

ولقدد اتسع مفهوم التعدديـــة النقافيــة لوجود أنواع من الأقليات التي أدى وجودها ونمو ها ومطالبها إلى نشأة التعددية الثقافيــة

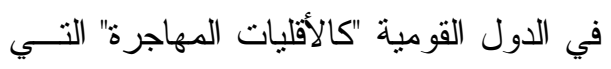

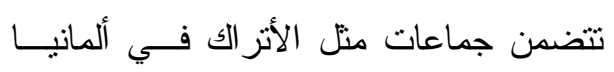

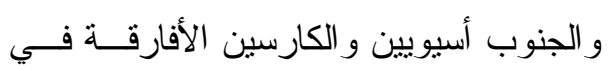

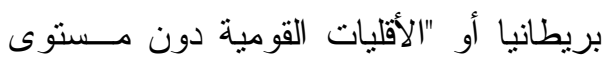
الدولة" منل سكان مقاطعة كيبيك أو الكنديين

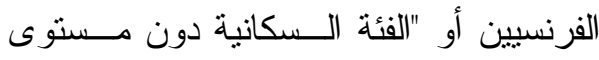
الدولة" مثل الأمريكيون الأفارقة وهم الــذين يتسمون بصبغة عرقية عاصرت بالفعل مولد الدولة القومية الأمريكية ولذلك فإن أصــــولها تختلف إلى حد بعيد عن المهاجرين هذا إلـى

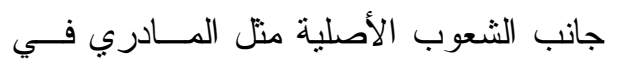

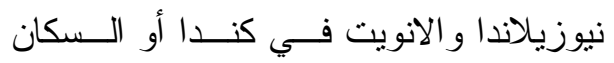

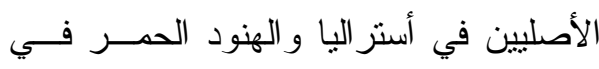
أمريكا والأمم الأولى في بريطانيا هذا إلـى لـى جانب الو افدين الأجانب الذي يرتحلون للعيش بلاني أو الكسب أو التعليم.

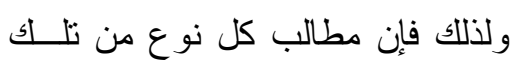

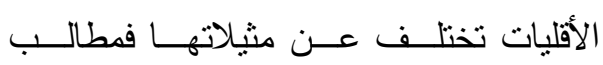
الأقليات الوطنية دون مستوى الدولة (الكيبيك

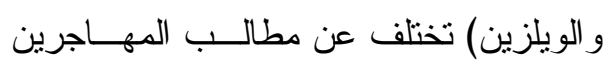




$$
\text { الإعلان العالمي لحقوق الإنسان و الذي منــل مبدأين رئيسين: }
$$

أولهما: أنه ينبغي أن تكون شــروط

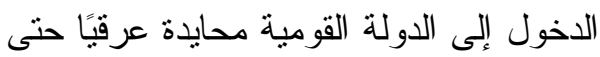

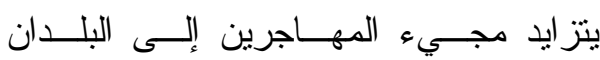

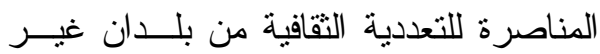

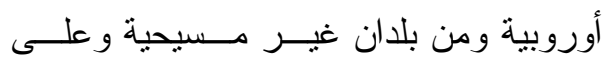

أغلب الظن وحتمًا من بلدان أغلبيتها مسلمة.

وثانيهما: أن يكون للمهاجرين الحرية

في الحفاظ على هوياتهم العرقية وأن يعبروا

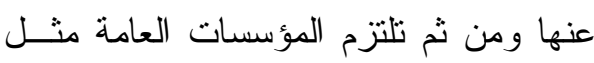

الشرطة و السلطات المحلية وخدمات الرعاية

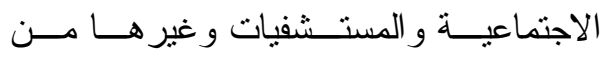

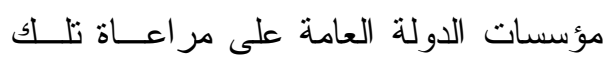

الهويات العرقية.(؟)

\section{سياسات التعددية الثقافية}

تتعدد سياسات التعددية الثقافية المطبقة

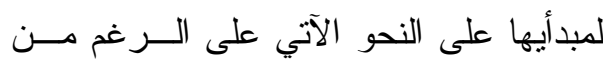

اعتمادها بدرجات متفاوتة في البلدان المختلفة

حسب طبيعة البلدان القومية وطبيعة الأقليات

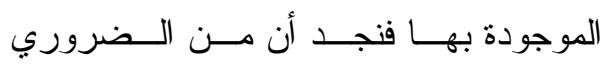

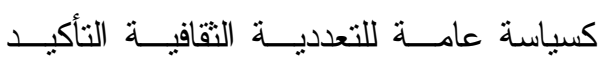

الدستوري أو النتريعي على التعددية الثقافية

(2) C. Taylor, the politico of Recognition. In A. Guttmann (ed.) multiculturalism and the polities of Recognition, Princeton university press, 1944, p, 30

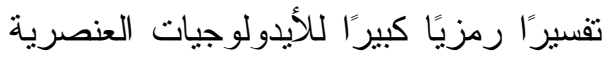

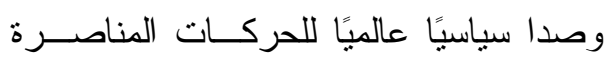

للسياسات العنصرية إلا أن نهيئة مناخ نقافي

دولي متعاطف مع حقوق الإنسان و المساواة

بين البشر لم تتحقق إلا بعد معارك مـستصرة

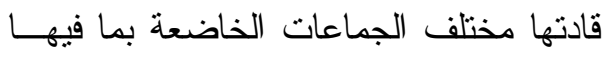

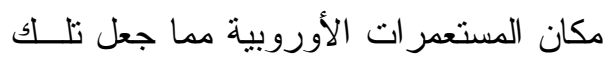

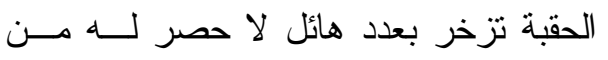

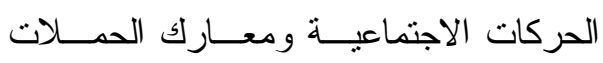

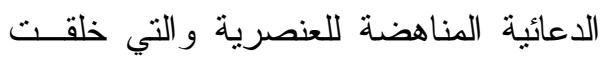

الأثز العميق في الثقافة الــسياسية و المدنيـــة

للايموقر اطيات الغربية والذي أبرز اتجاهين

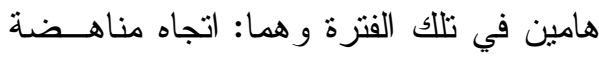

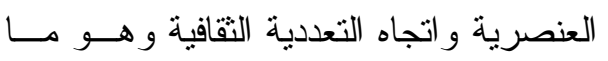

سمي في تلك الفترة "بسياسات الهوية" حيـــ رفعت مطالب الاعتر اف الثقافي و التي لعبت دورًا كبيرًا في إكمال و إتمام الكفاح اليساري و الليير الي من أجل إعادة نوزيع الثزوة. (')

مبادئ التعددية الثقافية

إن المسار ات التي ســــكتها التعدديـــة

الثقافية في البدان المختلفة تباينت للعديد مــن

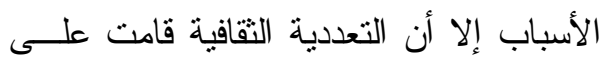

(1)على راتتسي: التعددية حقوق قصيرة جدًا، ترجمة

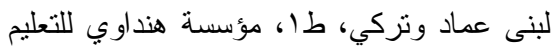

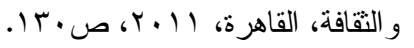




$$
\begin{aligned}
& \text { النقافية بما يسمى "نظم المو اطنة". (r) } \\
& \text { ثانيًا: عو امل التعددية الثقافية } \\
& \text { هناك عو امـلـل متعـددة تقــف ور اء }
\end{aligned}
$$

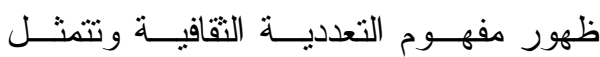

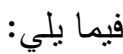

$$
\begin{aligned}
& \text { () ) عو امل تاريخية وجغز افية: } \\
& \text { كما أوضحنا فيما سبق فــإن مفهــوم } \\
& \text { التعددية التقافية ظهر جليُّا فــي ســنينات } \\
& \text { وسبعينات القرن العشرين إلا أننا إذا رجعنـــا }
\end{aligned}
$$

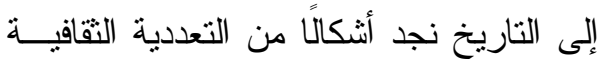

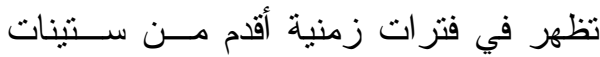

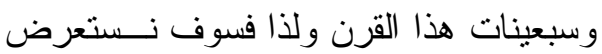

$$
\begin{aligned}
& \text { بشكل موجز نبذة مختــصرة عـن أثــكال }
\end{aligned}
$$

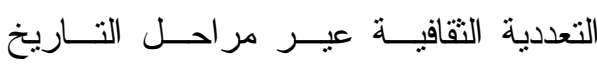

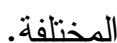

$$
\begin{aligned}
& 1 \text { - مرحلة الدولة الفرعونية القديمة: } \\
& \text { كان التعدد الثقافي قديمًا منذ الأزل منذ }
\end{aligned}
$$

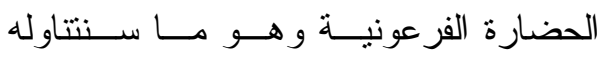

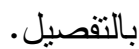

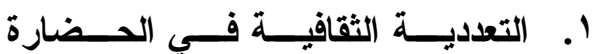

$$
\begin{aligned}
& \text { الفرعونية القديمة: } \\
& \text { أ. جامعة أون: } \\
& \text { تعد مصر القديمة مــن أقــدم الــبلاد }
\end{aligned}
$$

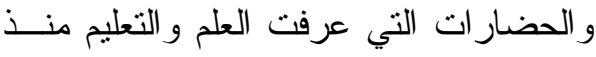

$$
\begin{aligned}
& \text { (r) على ر اتتسي: مرجع سابق، ص ب •r. } \\
& \text { على المستويين المركزي و الإقليمي وعلــى } \\
& \text { مستوى البلديات وكذلك تبنى التعددية الثقافية } \\
& \text { في المناهج الدر اسية و إدر اج تمثيل الأقليــات } \\
& \text { العرقية ومر اعاتها في إطار مهـام وســائل }
\end{aligned}
$$

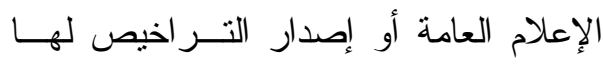

$$
\begin{aligned}
& \text { وكذلك الإعفاء من قو اعد الملبس و الإعفــاء } \\
& \text { من القو انين التي تمنع الاتجار في أيام الآحاد }
\end{aligned}
$$

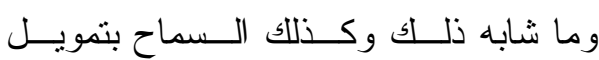

$$
\begin{aligned}
& \text { تتظيمات الجماعات العرقية من أجل تشجيع } \\
& \text { الأنشطة الثقافية وتمويل التعليم ثثائي اللغة أو } \\
& \text { التعليم باللغة الأم و اتخاذ إجـــر اءات إيجابيـــة }
\end{aligned}
$$

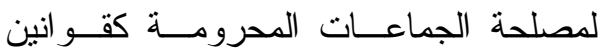

$$
\begin{aligned}
& \text { العلاقات العنصرية التي حرمت على نحــــ }
\end{aligned}
$$

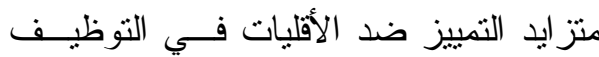

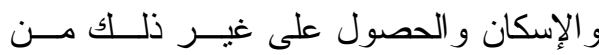

$$
\begin{aligned}
& \text { المو ارد وسبل الر احة و الثزفيه. (') ولكن على الإنى }
\end{aligned}
$$

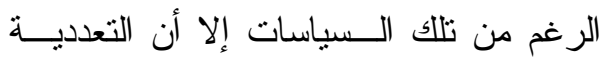

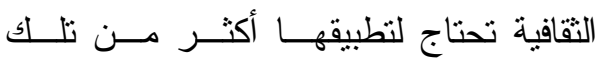

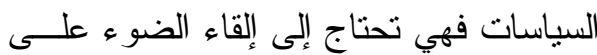

$$
\begin{aligned}
& \text { المسارات التاريخية المختلفة للتعددية النقافية }
\end{aligned}
$$

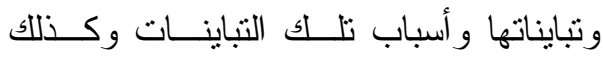

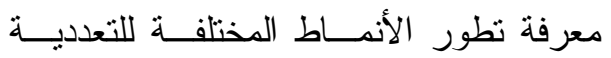


و اقتبسو ا منه ما ساعدهم على خلق الــدر اما

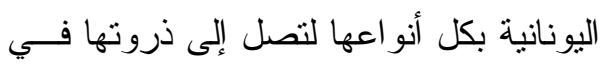

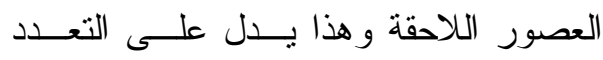

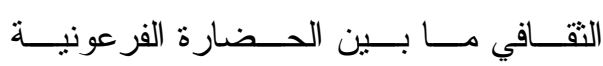

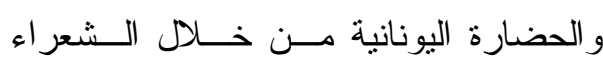
الو افدين إلى مصر مدن تعلمو ا بين رحابتها

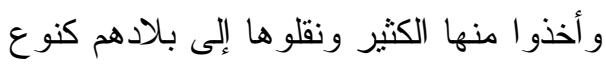
من أنو اع التعدد الثقافي.

هذا إلى جانب القصة المصرية التـي

أبدع فيها المصري القديم و أعطى لنا تــراث

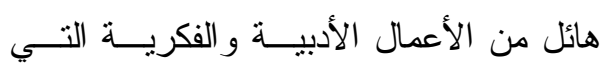

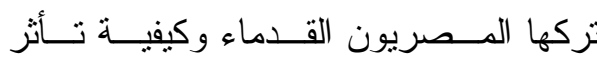
الأعمال الأدبية المصرية القديمة بالحضار ات

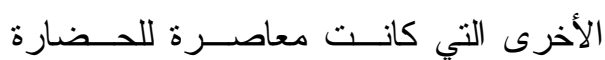

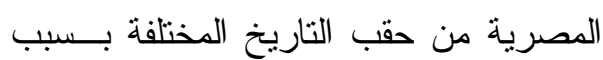
احتكاك المصريين القدماء بتلك الحــضار ات

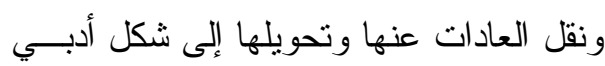
أو بسبب البعثات التجارية التي كانت ترسلها مصر إلى خارج حدودها أو بسبب الغزوات ات التئات و الفتوحات التي قامت بها الجيوش المصرية

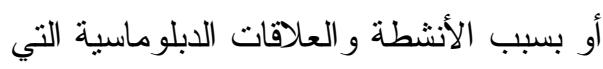

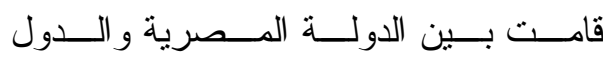

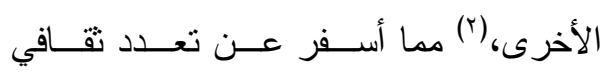

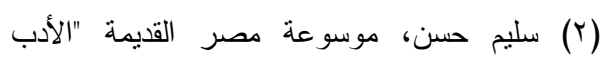

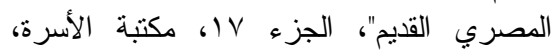

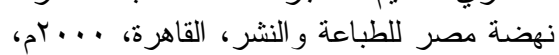

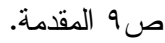

فجر التاريخ و التي أنـشـأت بــين رحابتهـــا المدارس و الجامعات بهدف تحقيــق تتميــة

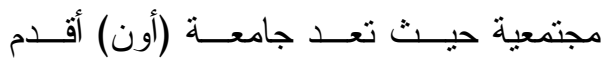

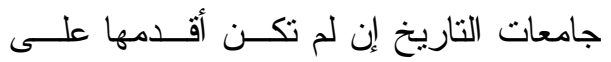

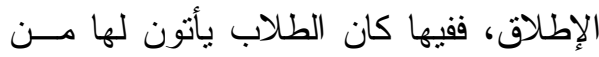

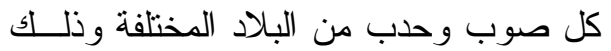

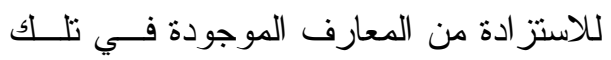
الجامعة مما بحدث شكلًا من أثنكال التعددية

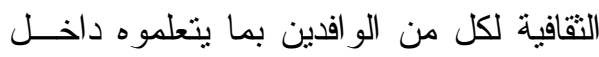

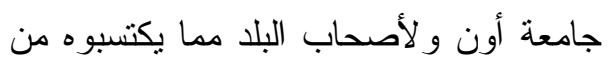

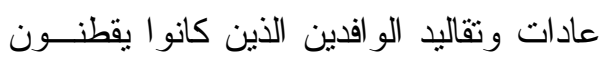

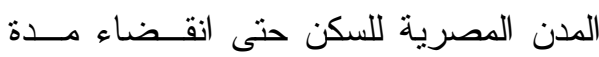
تعليمهم داخل جامعة أون. ب. الأدب الفرعوني (الثعر والمسـرح والقصة)

من المعتقد أن مهذ الدراما بنوعيهــا (المأساة و الهزلية) تأتي من الفكر و الحضارة

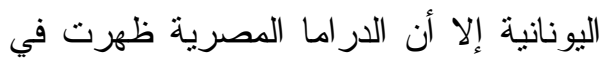

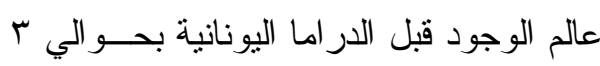

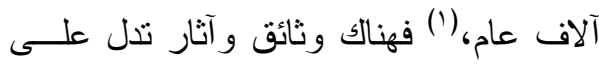
أن الأدب الفرعوني (شعر ومسرح) أقدم من الشعر و المسرح اليوناني مما يؤكد أنه عندما أتى اليونان للتعليم في مصر القديمـــة فــإنهم تأثرو ا بما رأوه من مسر ح وشعر فرعـي فئني

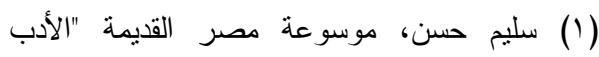

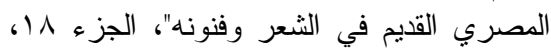

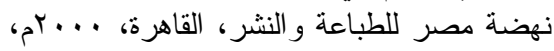


الإغريق حتى في الملابس، فنجد الملابـس الإغريقية مقلدة عن الملابس المصرية.

هذا إلى جانـــب أن رجــال الحكمـــة

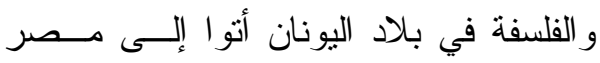

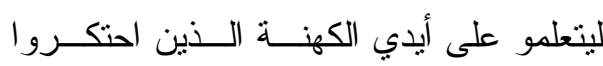
العلوم و الأدب فقد كان في كل مدينة عظيمة

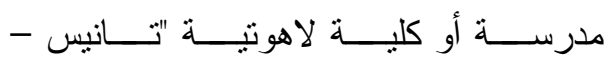

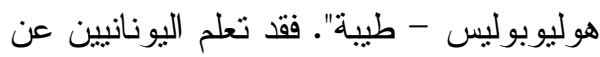

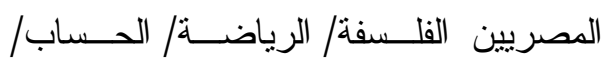
الهندسة/الكيمياء و الطب و الفلك وكــان مسن الكـ

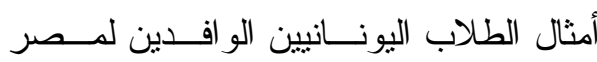
أمثال (تاليس - أناكزيمناندر - فيثاغورس هير اكلتيوس - لوسير - ديموكرتيوس). أ. بيث الحياة ومكتبة الإسكندرية:

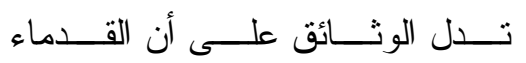

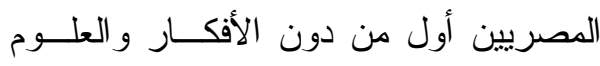
الدينية و الدنيوية على الورق وحفظوها فـي بيت الحياة (ير - عنخ) وبيت الحياة كانــت تقوم بوظيفة المكتبة فقد كان فيهــا العلمـــاء الباحثون في العلوم المصرية وكذلك المراجع

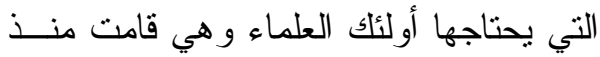

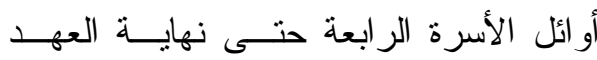

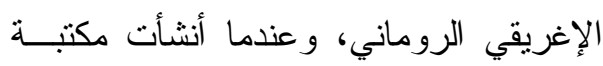
الإسكندرية في العهد البطلمي كان يوجد بها وعال

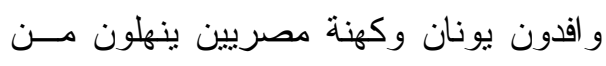
العلوم المختلفة في المكتبة مما أوجد بلا شك ونك
للحضارة المصرية وكذلك تعدد نقافي للبلدان

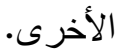
r - مرحلة الاولة البطلمية:

كان التعدد الثقافي أيضًا في مرحلـــة

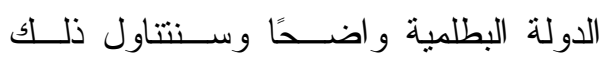
بالتقصيل. - التعددية الثقافية في العصر البطلمي: كانت لمصر القديمسة فـي عـصر الفر اعنة صلة وثيقة مع جزيرة كريت قبــلـ أن يظهر الثعب الإغريقي بصورة واضحة على مسرح التاريخ فقد كانت كريت متصلة بمصر اتصالًا وثيقًا فوجدت أثنياء مــصرية

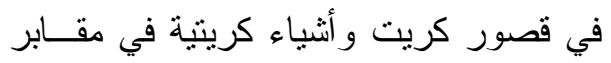
مصرية(') وعند ظهــور الإغريــق كانــت المسافة لمصر القديمة ضئيلة فسافر الإغريق إلى مصر جلبًا للعلم فكونو ا محطة تجاريسـة

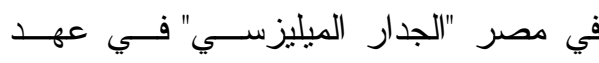
بسمتيك الأول"وفي أثناء اختلاط الإغريــق لئن بالمصريين بدأ الو افدون الإغريق يـشـعرون

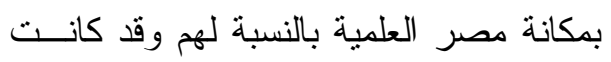

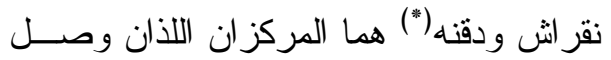
منهما تأثثير الثقافـــة المــصرية إلـى بــــلاد

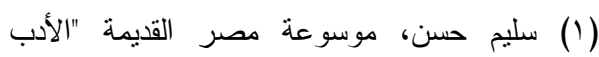

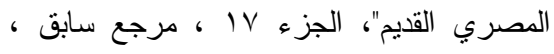
ص 9. (*) نقر اش ودقنه ددن اغريقية أنشأها الحاكم البطلمي على ضفاف نهر النيل من الناحية الغربية. 


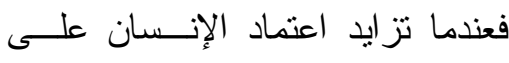

الآلات و المختر عات وبدأو ا في البحث عـنـن الآنـ

مصادر الطاقة واجتمعت جهــود الإنـسـان

لإنشاء المصانع و المدن الصناعية مما أثنـــر

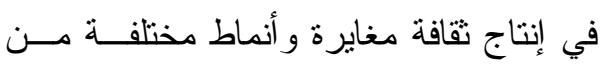

العلاقات و القيم و المفاهيم التي تحكم الأثـــياء

و الأفر اد و المجتمعات في المجالات الصناعية

و الأنشطة الحياتية. (r)

\section{؛ - مرحلة الدولة المصرية الحديثة:}

يؤر خ لتلك المرحلة منذ نولي محمــد

علي باثا حكم مصر في عام 0 .11 ورغنبته

في بناء دولة قوية لمصر فبدأ بإرسال بعثات

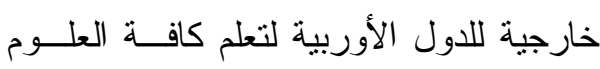

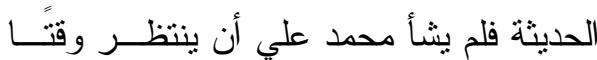
طويلًا حتى ينتظم حال المـــدارس الابتدائيــة

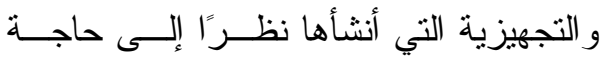
البلاد إلى الموظفين، فبدأ محمد علي بعدــل فئل هرم تعليمي مقلوب و إنشاء (مدارس التعلــيم لـيم

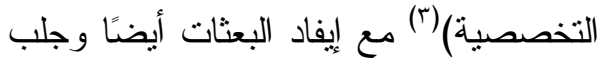
المدرسين الأوربيين إلى مصر لتعليم الجيش

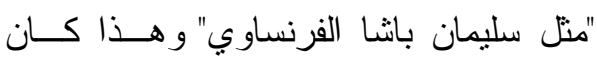
بمثابة تعدد ثقافي داخل البلاد ونظرًا لــسفر لـانيا

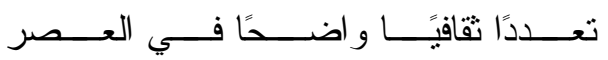

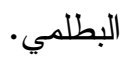

ب. التوفيق بين الإغريق والمصريين من

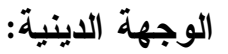

حتى في الدين فنجد أن فــي العــصر البطلمي تم التوفيق بين الإغريق و المصريين

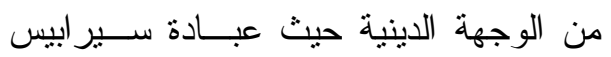

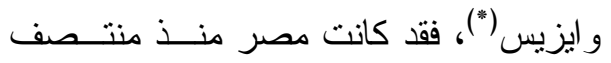
القرن السابع قبل الميلاد وقبلة الإغريق الذين

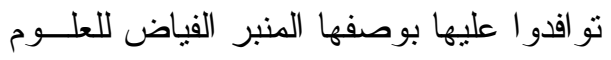
و المعارف و هذا ما جعل لديهم تعدد ثقــافي لئي

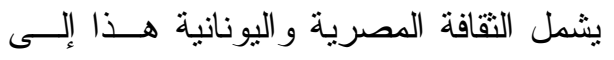
جانب أخذ المصريين لبعض العـادات فـي ولي الملبس و المأكل من بعض اليونانيين المقيمين في مصر أثناء العهد البطلمي. r- مرحلة الثورة الصناعية:

قامت الثورة الصناعية فــي بــدايات القرن 11 حيث استخدم الآلات بشكل كبيــر

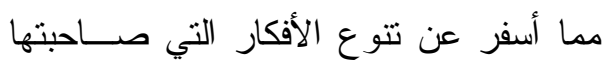

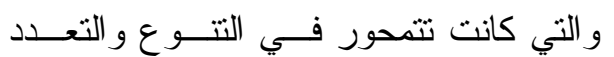
الثقافي و العمل كقوة و احدة. (') (") سير ابيس و أيزيس: الهتان مصريتان عند اليونان في العصر البطلمي و أنثأو الهما المعابد.

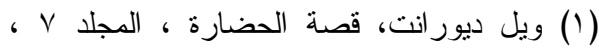

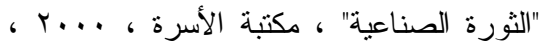

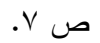


الاستعمار كنزوح بعض السكان الأصــليين إلى الامبر اطوريات الاستعمارية كالرقيق أو الونئن

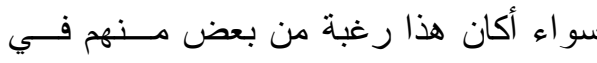

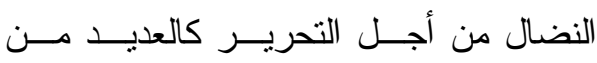
الشخصيات كغاندي فأدى ذلك إلى اندماجهم مع بعض أصحاب المـستعمر ات أو أيــضـا كرد فعل لبعض النزعات التحررية و التـي أدت إلى استقلال البلدان المستعمرة مع وجود

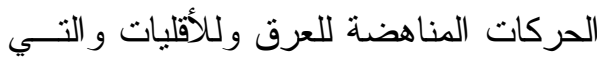
كانت تتادي بحقوق الأقليات ونبــــ العنــف و التمييز العرقي تجاههم.

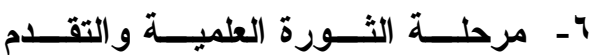

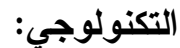

كان أحد الأسباب الرئيـسية لظهــور

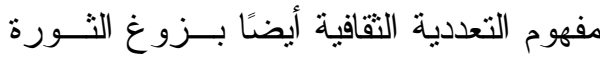

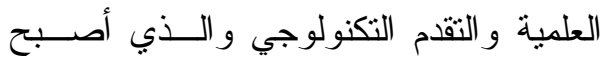

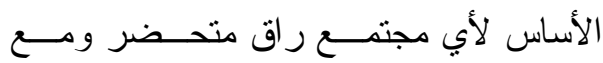
وجود العولمة والعالم الذي أصبح عبارة عن لأن

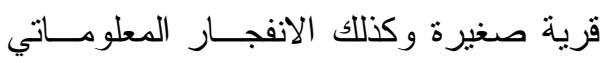

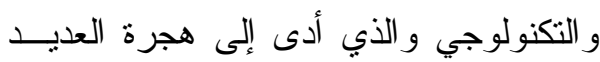
من سكان بعض البلدان إلى منـــاطق أكتــر رقيًا في منل هذا المجال وذلك من أجل العلم

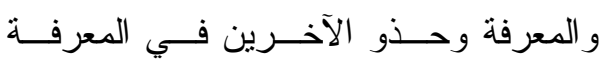
و الحصول على مكاسب من الثثورة العلميــة و التقدم التكنولوجي و اللحاق بركــب التقــدم و الرقي هذا إلى جانب أن العولمـــة و انفتـــاح

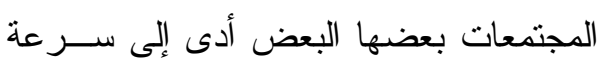

أعداد متز ايدة من الطلاب الدـصريين إلـى جامعات أوربا وتــأثر هم بالحيــاة الجامعيـــة و التقاليد العلمية تز ايدت النداءات و الــدعوات لإنشاء جامعة على الطر از الأوربــي لنلبـي لني احتياجات مصر من الكو ادر و اللحاق بركب الإنباء

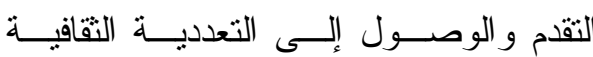
المطلوبة لمو اجهة التحديات.( ) هـ - مرحلة الفكر الاســتعماري وتــصاعد

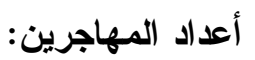

إن الفكر الاستعماري الذي بــــأ قبــلـ

الحرب العالمية الأولى واستمر بعدها لقرون

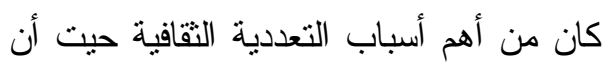
وجود الامبر اطوريــات الكبــــى كـإنجلتر ا وفرنسا و استعمار ها للعديد من الدول ســو اء أكانت داخل القارة الإقريقية أو داخل آســيا

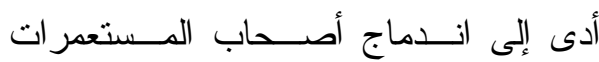

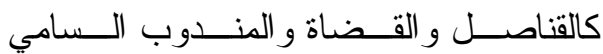
و الصحافيين وكل هؤلاء كان لهــم احتكــالك

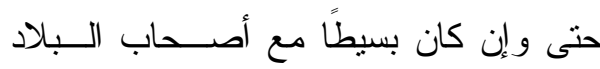

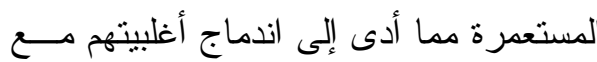

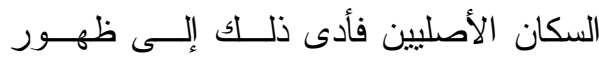
التعددية الثقافية هذا إلى جانب تصاعد أعداد المهاجرين كرد فعل سواء أكان هـــا أيــام (1) محمد سعد عبد الحميد، الجامعة ورسالتها،

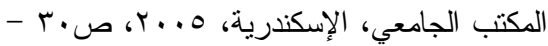

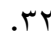


مفهوم التعددية الثقافية فالعالم ما هو إلا قرية

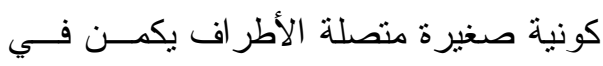
داخلها كلًا من إعادة توزيع الموارد الطبيعية

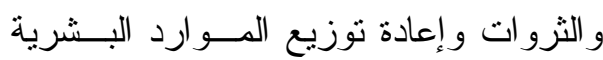

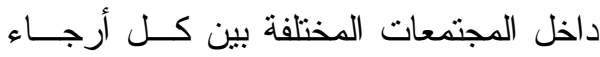
العالم وكذلك فهي تدعو إلى إز الة الحـــواجز بين المجتمعات لترسيخ مفهوم القرية الكونية

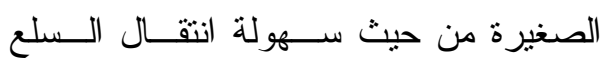

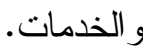

وتتعدد مظاهر العولمة في المظهـر

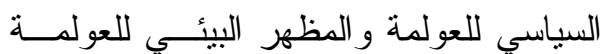
و المظهر الثقافي و الاجتماعي للعولمة حيــث

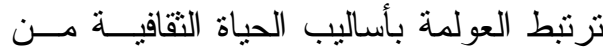

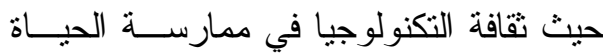
اليومية و الثقافة الاستهلاكية وتز ايد معـدلات

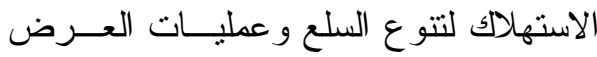

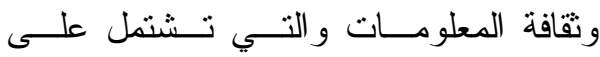
استخدامات المعلومــات وتتميــة مهــار ات التعامل المعلوماتي فنقافة العولمة تسعى فــي جو هر ها إلى تكوين مستوى ثقافي عـــولمي

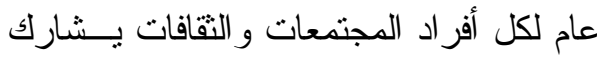

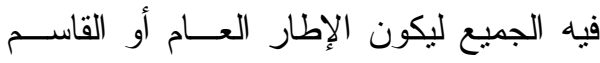

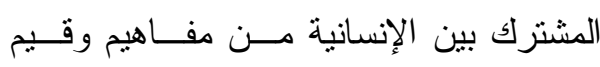

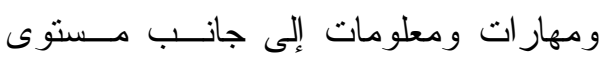
ثقافي خاص تتميز به كل ثقافة فرعية تحافظ على ثو ابتها وتسعى إلى تطوير متغير اتها.
التو اصل بين المجتمعات المختلفة و أتاحــت

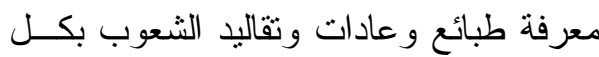
سهولة ويسر فأتاحت التعرف علـــى الآخــر

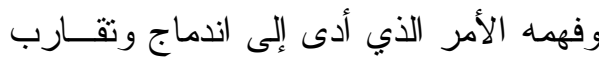
المجتمعات بعضها البعض مما أسفر عن فهم المراجي أكثر لمفهوم التعددية الثقافية وظهوره بشكل

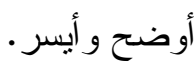
ثانيًا: عوامل فكرية وتربوية: ا - ـ مرحلــة تــــاخل التـــــارات الثقافيــة

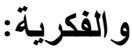
إن تداخل النيار ات النقافية و الفكريسـة داخل المجتمع كان أحد العو امل ور اء ظهور مفهوم التعددية الثقافية حيث أن تداخل القوى الحضارية المتسقة في صر اع فكري ونقافي

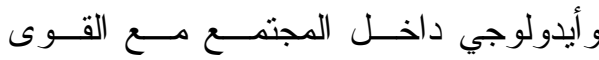
الحضارية المنصار عة أدى إلى ظهور مثنـل

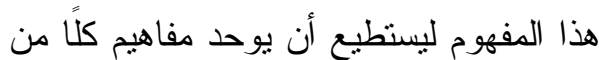
القوى الحضارية المتسقة والقوى الحضارية المتصـار عة حول الوصول إلى حالـــة مــن التصالح و الاندماج و التعايش داخل المجنتـــع

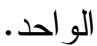

r- مرحلة تطبيق مفهوم العولمة ثقافيـاً و اجتماعياً:

إن تطبيق مفهوم العولمة أصبح مـن الصن

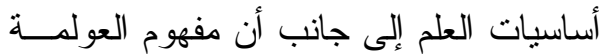

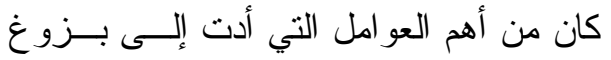


أما اجتماعية العولمــة أو المظــاهر راغبيه دون حواجز أو فو اصل مجتمعية أو

الاجتماعية للعولمة فإن العلاقات الاجتماعية مكانية.

ويتضح التعليم العولمي في المؤسسات

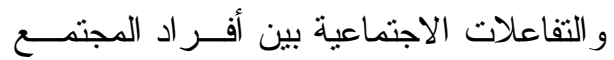

التعليمية المدرسية و الجامعية الغربية القريبة

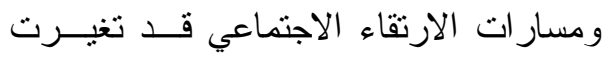

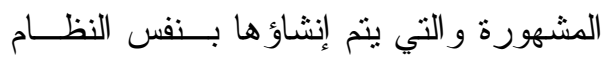

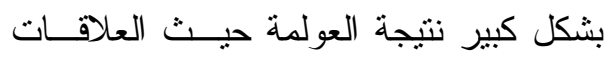

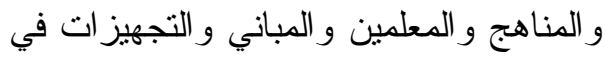

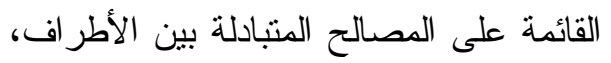

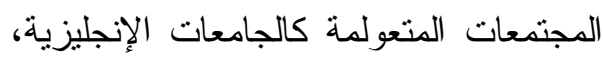

كما أن حقوق الإنسان أصبحت من المظاهر

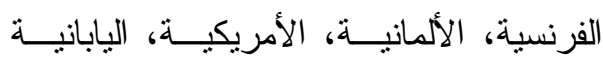

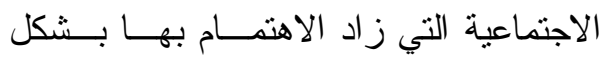

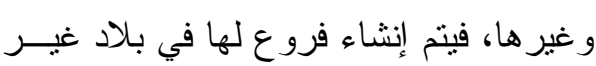

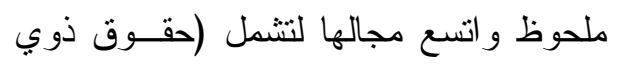

بلد المنشأ تقبل فيها طلاب من سكانها وبهذا

الاحتياجات الخاصة - حقوق المرأة و الطفل

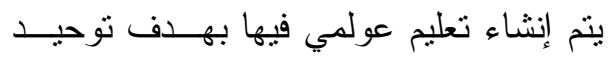

- حقوق الأقليات و الفئات المهمشة). (1)

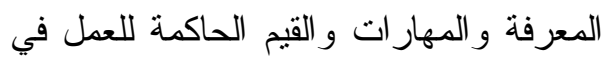

r - مرحلة التعليم العولمي:

$$
\text { المهن المرنبطة بها. }
$$

هذا إلى جانب الجامعات الافتر اضـــية

ونظم التعليم عن بعد التي تعمل على مستوى

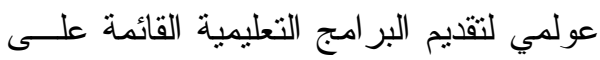

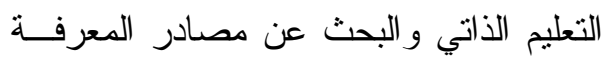

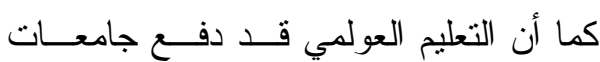

تقليدية على عمل بر امج للتعليم الإككترونـي لئي

عن بعد وكذلك فصول در اسية للو افدين مسنـ

بلدان أخرى لتقديم فرص تعليم منميزة تحقق ولق

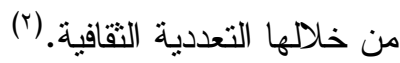

ويقصد بالتعليم العــولمي أو عولمـــة

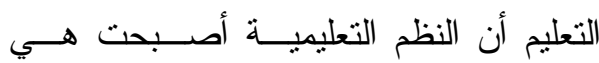

الأخرى منصهرة داخل بوتقة القرية الكونية

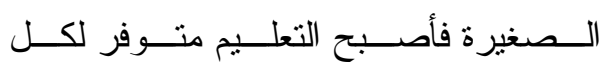

الأشخاص في كافة المجتمعات و أصبح التتقل

من قبل الأفراد لتلقي التعليم في أي بقعة من

بقاع الأرض لأمر غاية في السهولة فبعد أن

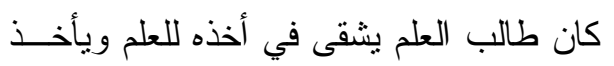

شهورًا كثيرة وربما سنو ات لكسب العلم فإن

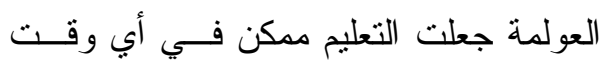

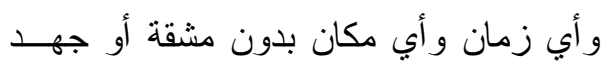

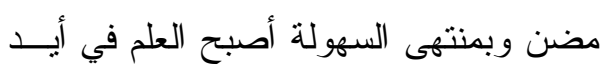

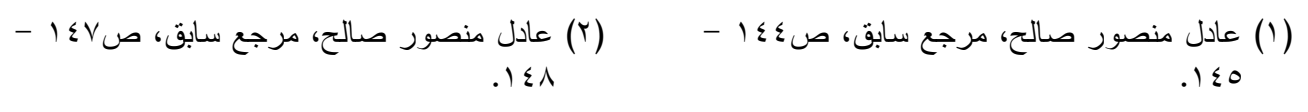


الثقافي بين الثقافات الفرعية الأصلية للمجتمع

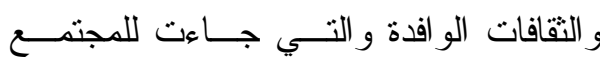

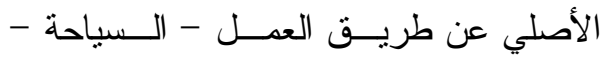

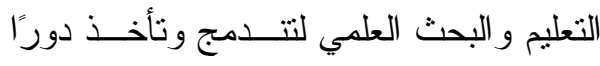
داخل المجتمع الو احد نذكر منها على سـبـيل

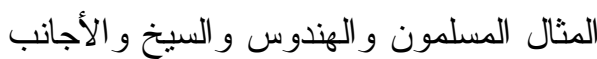

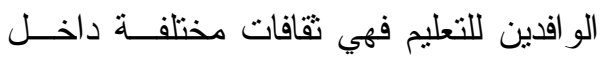

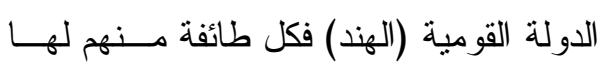

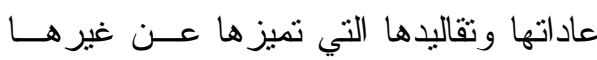
ولكن يجمعهم وطن و احد ودولة قومية و احدة

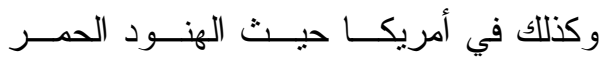

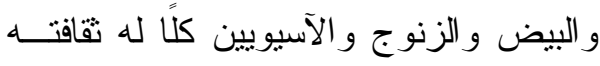

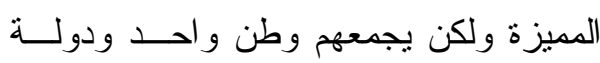

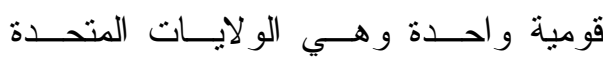
الأمريكية. ب- التعددية الثقافية الخارجية: وهي التي تعني التعدد التقافي ما بين

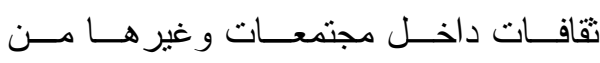
المجتمعات الأخرى ويحدث هذا من خــلدل انخر اط أفر ادها داخل أحد المجتمعين بغرض الاخري العمل أو التعليم أو اكتساب مهار ات خاصـــة دكنة

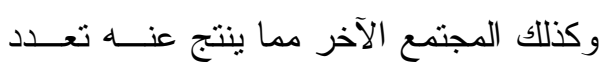

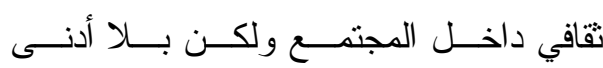
صر اعات داخل المجتمع الو افد إليه الثقافات الأخرى لا من حيث التماسك أو تغير أنماط

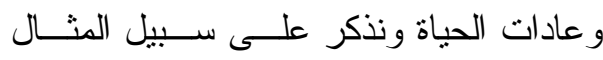
البلدان العربية و استقبالها لأفر اد مــن بلــــان

\section{צ - مرحلة الثورة المعلوماتية:}

تتميز المجتمعات متعــددة الثقافــات

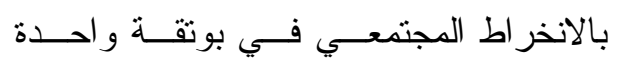
تعليمية/ ثقافية/ اجتماعية مع أثنكال التعددية

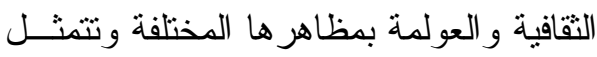

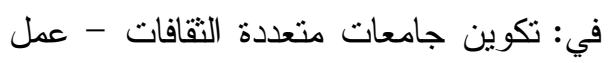

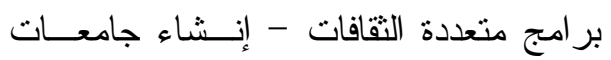
أجنبية تستوعب تعدد الثقافات حيث المجتمع

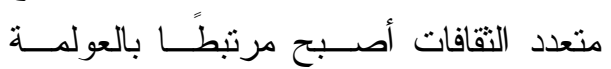
كمرحلة تاريخية لها خصائصها ومقومسات

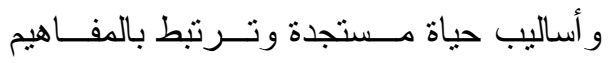
و الأفكار التي تقوم عليها فلسفة العولمة التي أصبحت لها تأثثر على المفــاهيم و الأفكــار

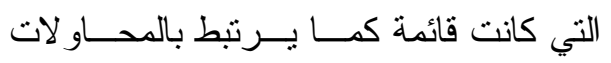
العلمية الو اقعية للممارسات المعبرة عن تلائك الظاهرة كنظام عالمي جديد يسعى إلى التعدد

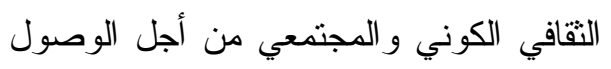
إلى عالم منغير يسع الجميع. (1) ثالثًا: مستويات التعددية الثقافية

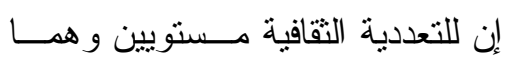
ينحصر ان في تعددية ثقافية داخلية وتعدديــة ثقافية خارجية.

\section{أ- التعددية الثقافية الاخلية:}

وهي تعني التعـدد الثقــافي داخــل

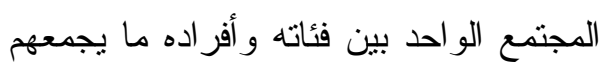

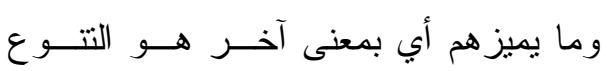

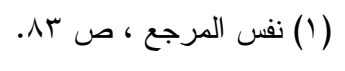


الانتشار العالمي للتعددية الثقافية وذلك مـن خلال أعضاء يكونـــون فريــق عمــل مــن

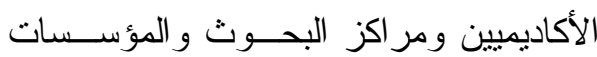

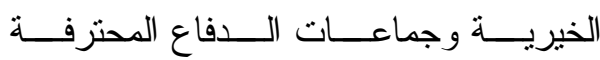
كمستشارين يصوغون أور اق العمل ويعملون كثركاء في مشاريع وبر امج متر ابطة بمســا

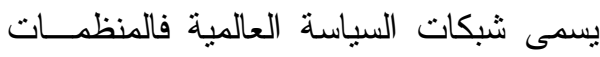
الدولية هي التي تصيغ المعايير و المةــاييس في مجال التتوعات العرقية وشبكات السياسة العالمية وهي التي تساعد المنظمات الدوليــة في هذا المجال فتملك تلكك المنظمات تفويضًا للحديث نيابة عن الدول الأعضاء وهي بذلك تمثل المجتمع الدولي و إن كان من الــسذاجة

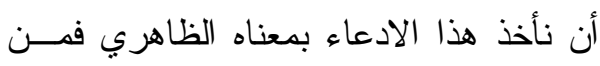

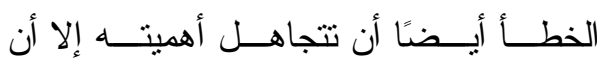

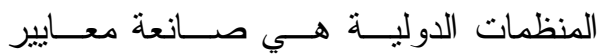

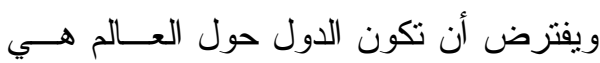
متلقية المعايير وتلك العلاقة هي المفتاح لفهم مفارقات السياسة الدولية الجديدة للتنوع.

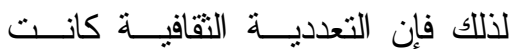
و لاز الت محل جدل و اســـع فــي النقاثـــات

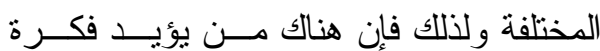

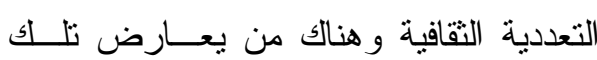

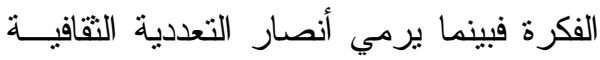

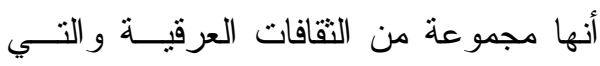

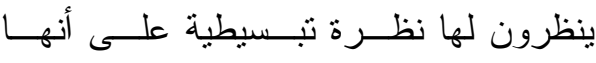
متجانسة وذات خصائص ثابتــة و أساسـية لفية

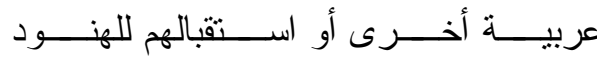
و الباكستانيين من أجل العمل أو التعليم مما لا لاهيل يؤنز على المجتمع ذاته. رابعًا: التعددية الثقافية بين التأييا و الرفض: بعد أن تتاولنا مفهوم التعددية الثقافيــة

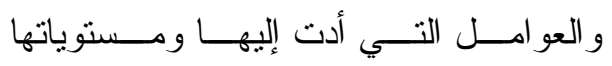
سنتطرق الآن إلى المؤيدين لفكرة التعدديـــة

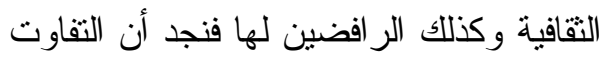

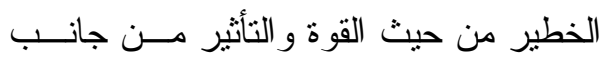
الدول الغربية في تطبيق التعددية الثقافية من

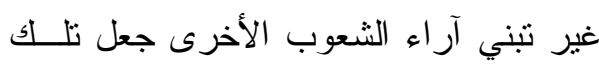

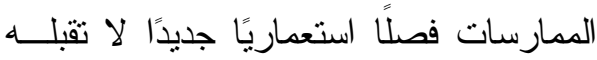

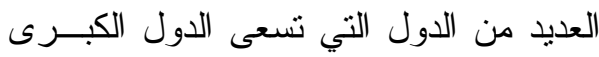
إلى الهيمنة عليها باسم المجتمع الدولي تــارة

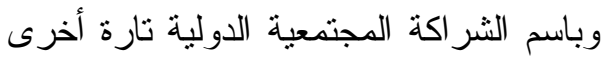
حيث لا نر اعي تلك المسميات مصالح بـاقي المجتمعات في العالم و اكتقت تلك المـسميات

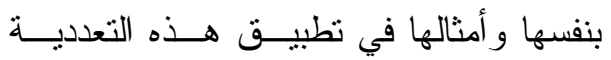
الثقافية حيث الخطط التي تسعى من خلالهـــا على تتمية وتشجيع التعددية التقافية لا تعكس عن قيم المجتمع الدولي المتحد كله. الأمر الذي يجعل العديد مــن الدولـــة

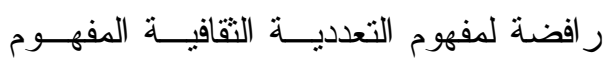
المفروض عليهم من الخارج بغير الأخذ في

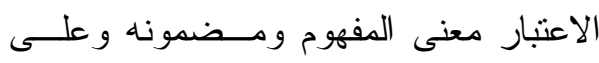

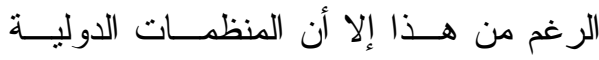

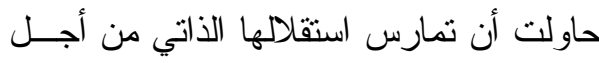


عن الإطار المشترك للدولة فينتج عنه عـدة دول داخل الدولة الواحدة. (1)

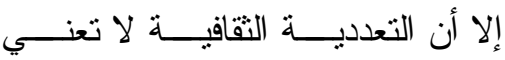

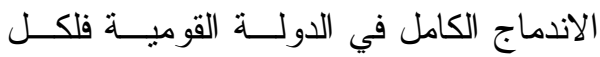
مجتمع عاداته وتقاليده التي لا يستطيع التخلي

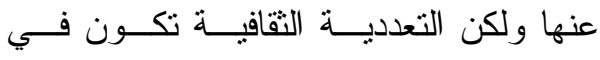
المساو اة في وسائل الحياة المختلفة وليس في الفكر الثقافي للمجتمعات ومسـن الممكـن أن تأخذ ما هو جيد من ثقافة الو افد أو المهــاجر داخل إطلار الدولة القومية بما لا يؤثز ســلبًا عليها و على معتقداتها وقيمها الأصلية، فنجد أن المؤيدين لفكرة التعددية الثقافية بــروا أن تللك الفكرة تميزت بعدة مفاهيم منها التعــدد حيث وجود أكثر من ثقافة واحدة في المجتمع حيث التعرف على الثقافـات الأخــرى فــي المجتمع عاداتها وتقالبدها وقيمها و الاعتر اف بشرعية تلك الثقافات وتعددها داخل المجتمع على أنها مركب هام وجزء لا يتجــز أ مــن المجتمع وكذلك يروا أيضنًا أهمية الاخــتلاط حيث ضم أجناس مختلفة أو ثقافات مختلفــة في مجتمع ودائرة و احـــدة يجمعهــــا إطــــار

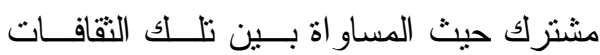

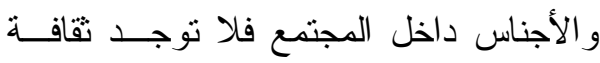

(1) B. Barry, Sociologists, economists and democracy, university of Chicago press, 1988, p. 179
وجوهريــــة ور أو أن المجتمعـــات متعـــددة

الثقافات هي أنية تحتوي على ثقافات عرقيــة منفصلة لا تمس أحداها الأخريات و أحرزوا معنى للعنصرية باعتبار هــــا تحيـززًا غيــر عقلاني يمكن القضاء عليه من خلال التنقيف عن الثقافات الأخرى وكذلك فالتعددية التقافية تعطي فرصة لتحقيق الحريات و المساو اة بين

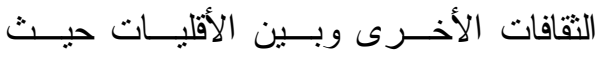
المساواة بين الثقافات المختلفة بحيث لا توجد هرمية وثقافة و احدة مسيطرة مما يؤدي إلى إهمال الفوارق بين الهويات لإنتاج خلق و احد متعدد ومركب متعدد ذو صــبغة مسـشنركة وكذلك فإن سياسـات الدولة هي التي تكـــون أحبانًا قاصرة على توفر الاندماج للأقليـات بينما يرى معارضو التعددية الثقافيــة أنهــــا فاثلة لأنها تتهي الدولة القومية ذات النـسيج الو احد وتعمل على تفككيها و إضعافها إلـى جانب أن الأقليات لا تستطيع الاندماج مـــع الدول القائمة حسب طبيعتها وقيمتها و عاداتها التي لا تشتطيع التخلي عنها كما أن التعددية التقافية يمكن أن تؤدي إلى عــدم اســتقرار جماعي وفوضى اجتماعية بسبب الاخــنلاف في القيم و العادات كما أنهـــا تـسـاعد علــى انغلاق الثقافة على نفسها وتكوين إطار بعيد 
ويرى أيضًا الر افضون للتعددية أنهـــا

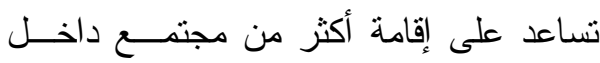

المجتمع الواحد حيث نجد أن التعددية التقافية

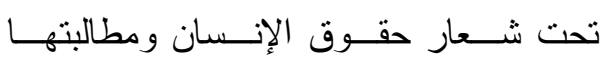

بالاعتر اف بالجامعات الثقافية المتعددة داخل المجتمع الواحد مما يؤثر على تماسك نـسـيج

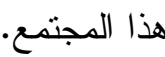

\section{خامسًا: نظريات تفسير التعدية الثقافية:}

توصلت علوم الثقافة والاجتماع إلـى

مجموعة من المفاهيم التي تـشكل نظريــات

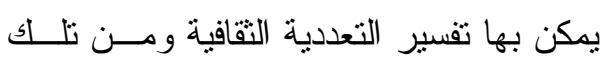

$$
\text { النظريات: }
$$

\section{1- النظرية التعددية الجماهرية:}

إن النظرية التعددية الجماهرية هـي الضامنة لتحقيق رغبات أغلبية الأفر اد وهي

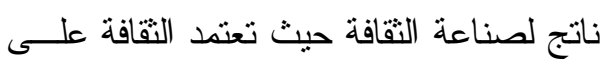

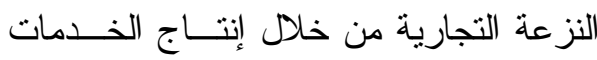

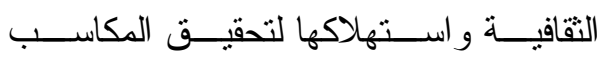
والأرباح القصوى فأسلوب الحيــاة الثقافــــة

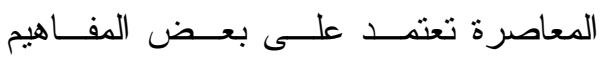

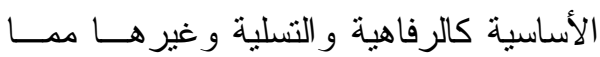

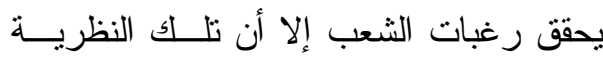
باتت في خدمة أصحاب الــسلطة و الثــروة

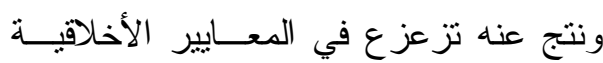
و السلوكية ور افقها امتهان للشخصية الإنسانية
هرمية و احدة مسيطرة داخــل المجتمــع.(')

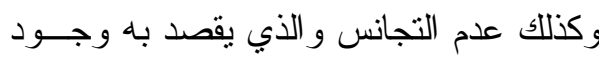

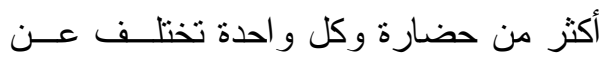

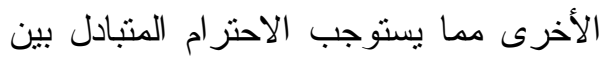

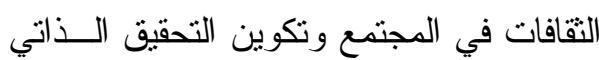
للفرد و الثقافة في المجتمع منل سن القــــــن انين

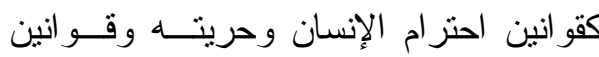

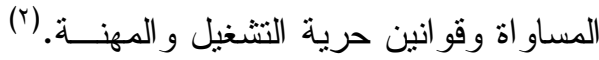
أما عن النسبية فيرى المؤيدون أنها تعني أنه ونه

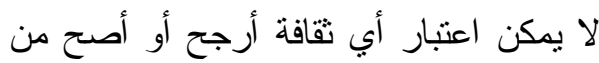

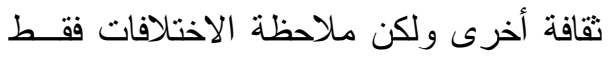
و القبول بالنسبية يعني إخر اج الثقافــة مــن

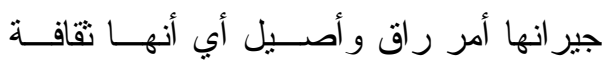

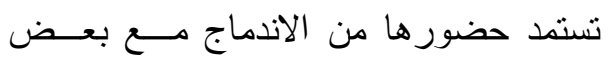

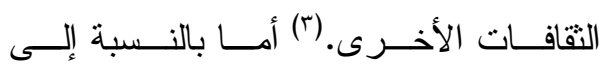
الر افضين لفكرة التعددية الثقافية فهم يروا أن

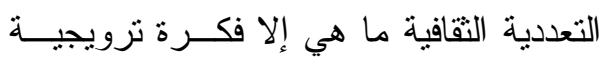
للتقريق حيث جاءت فكرة التعددية التقافيــة من قبل الدول والامبر اطوريات الاستعمارية وليس من خلال المناهــضون و الناثـــون لئن العرقيون أي أنه مفهوم استعماري أكثر مـن

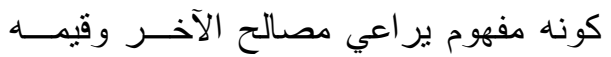
وثقافته داخل المجتمع الو احد.

(1) It is available at http://ar.farhangaelm.com It is available at http://www.hindaui.org/kalemat,2012

(1) It is available at http://www.wikpwdia.org 
التعددية لأنه نم التركيز في تلك النظرية على

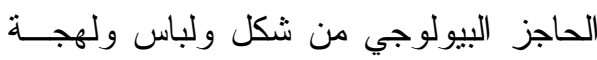

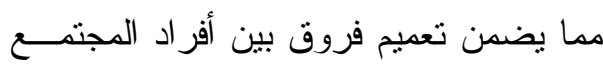

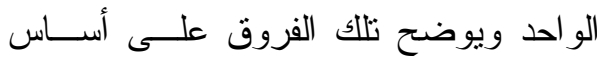
وجود أقليات وليس وجود أناس مشتركة في

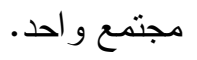

\section{نظرية النزعة المجتمعية:}

نشأت نظرية النزعة المجتمعية فـي

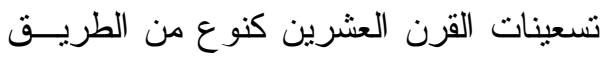

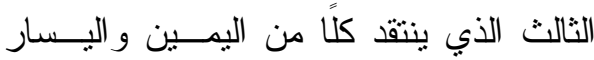

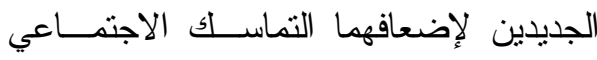
الذي كان يبقي على وحدة المناطق المحليــة و المجتمع ككل فنجد أن ممثلي الأول (اليمين)

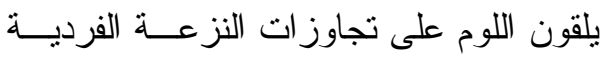

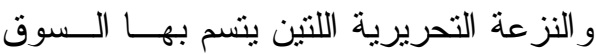

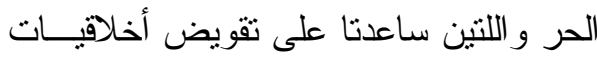
المسئولية الاجتماعية وقو اعد المعاملة بالمثل بينما تلقي اليسار لومًا علــى تبنــي اليمـين

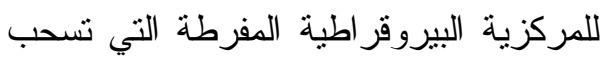

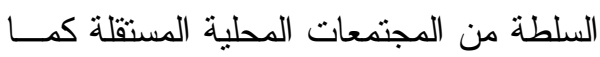
ينبغي ولم تقدم سوى القليـلـل مــن العــون

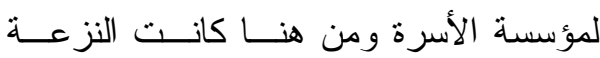
المجتمعية الجوهرية ما هي إلا حالـــة مسـن فئن

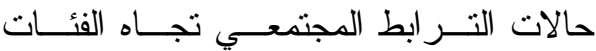
الاجتماعية المنتمية إلى الأقليـات العرقيـــة

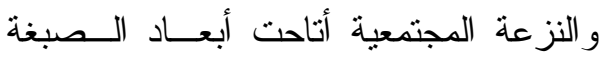
العرقية عن مفهوم التعدديـــة الثقافيــة إلا أن الن
وبذلك تكون نظرية التعددية الجماهرية هي إلا همجية و انفلات أخلاقي. (') r- نظرية الاتصهار (السلطة):

وتــسمى أيــضـًا نظريـــة الــسلطة و المقصود بتلك النظرية هي صـــر جميـع الثقافات الو افدة إلى الدولة القومية داخل ثقافة

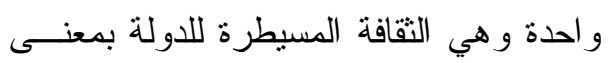

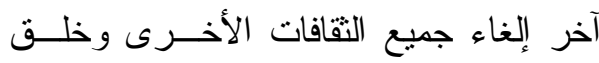
ثقافة جديدة صاحبة سمات متشابهة ولكن في تللك الحالة من الممكن أن تفثل ثلانك النظرية لبعدها عن مفهوم التعددية وهو تعزيز التتوع

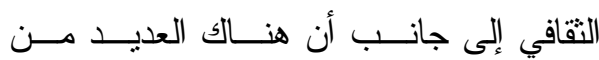
الفجو ات داخل المجتمعات الواحدة مما يؤدي إلى فنثل تطبيق تلك النظرية. r- نظرية الستيريوتيب أو نظرية القولبة: وهي نظرية المقصود بهــا تــصنيف

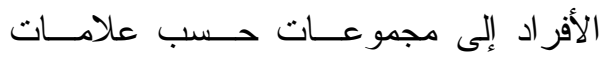

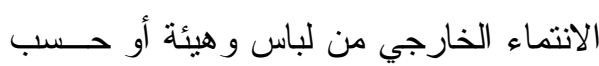

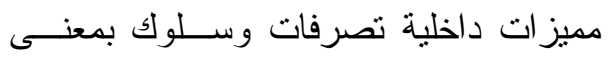

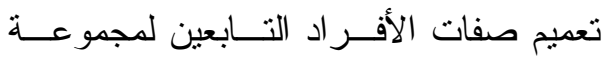

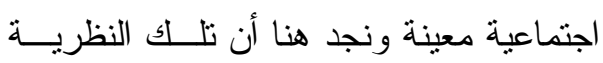

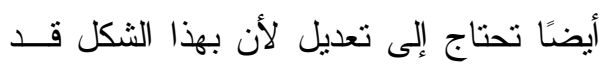
توجهنا بشكل أو بآخر نحو العنصرية وليس لعان لهان

(1) John Rawls, A theory of justice , Harvard university press, 1971, p. 202. 
يعتبر مؤديًا لمستويات منخفضة مسـن رأس المال التو اصلي يمكنها أن تؤلف بين عناصر

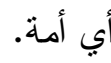

سادستَــا: مجــــالات التعدديــــة الثقافيــــة

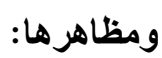

هناك العديد من المجالات التي تدخل

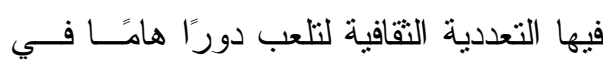

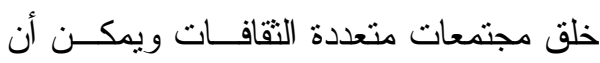

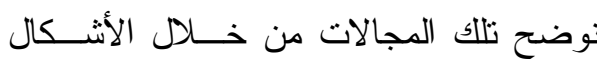
التوضيحية و التي يوضح بها أوجه التعدديـــة

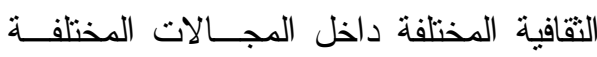
تعليمية - صحية - اجتماعية وترفيهيــة ثقافية ومعلوماتية.

$$
\text { 1 - المجال الصحي: }
$$

هناك العديد من أوجه التعددية التقافية في المجال الـصحي وهـــا مـــا ســنتناوله

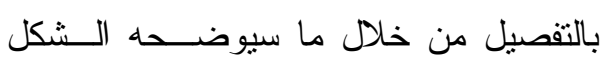
(')

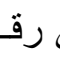
التوض
أحيانًا بكون التمييز العنصري و التحرش سبيًا

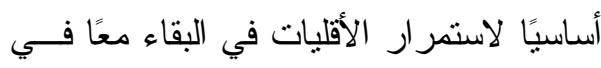

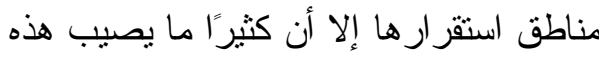

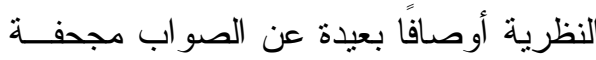
في حق الفئات المنتمية للأقليات. ع - نظرية رأس المال الاجتماعي (*) إن ارتفــــاع مـــستوى ر أس المـــــال الاجتماعي يتيح للمشاركين فــي الــشبكات

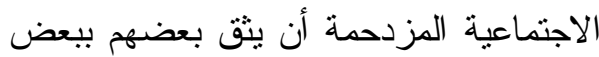

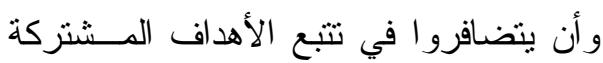

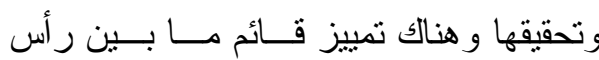
المال الاجتماعي الترابطي وهو يتعلق بخلق تلاحم داخل مجتمعات محددة فهو يجمع بين

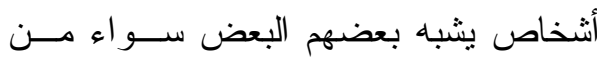

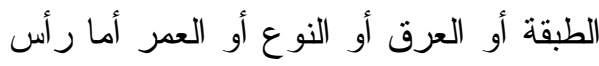

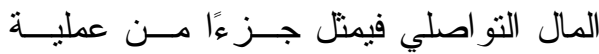
تكوين شبكات مجتمعية متداخلة لمجتمعسات

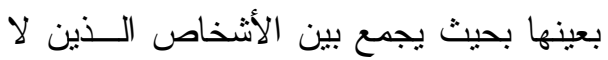

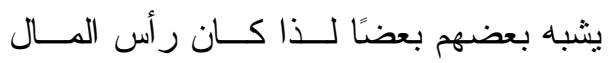
التو اصلي هو عنصر حيوي يمكن به تحقيق

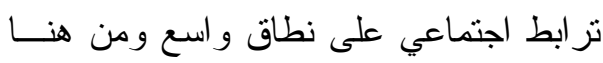

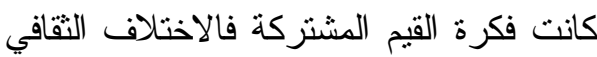

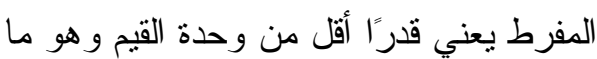

(") رأس المال الاجتماعي: هو العلاقة القائمة بين

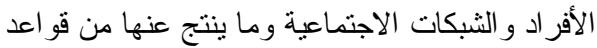
المعاملة بالمنل و المصد اقية. 


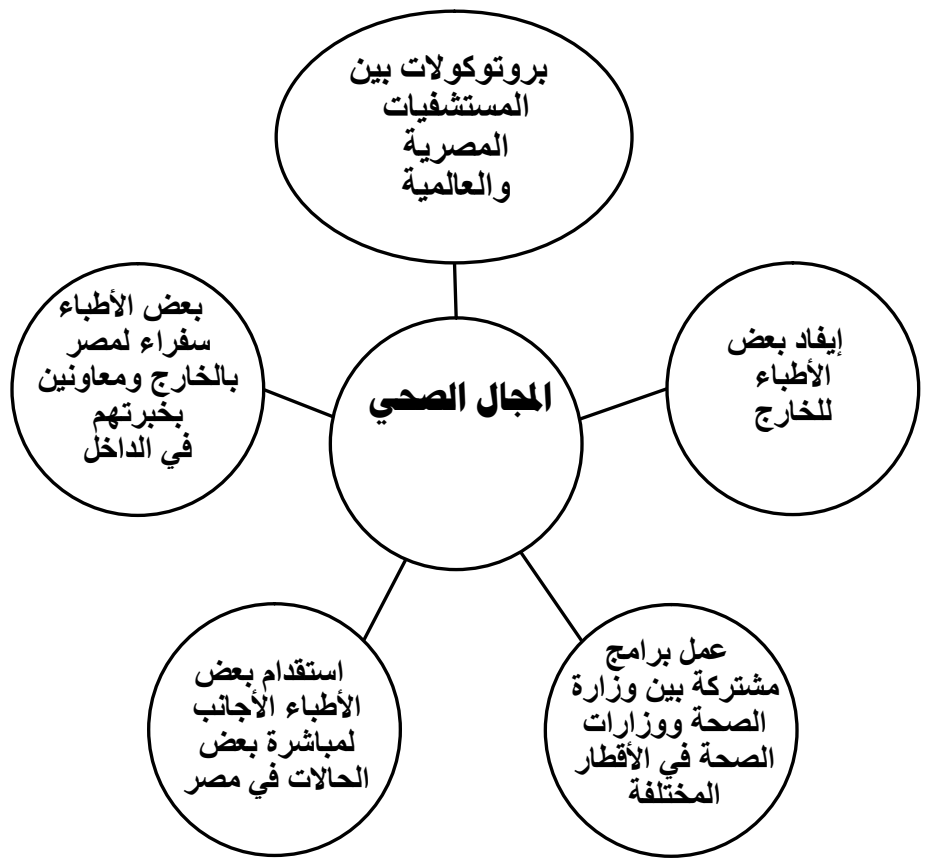

ج. عمل بروتوكولات بين المستـشفيات أ. إيفاد بعض الأطباء للخارج المصرية و العالمية:

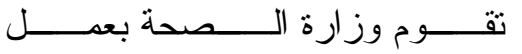

وذلك من خلا إيفاد بعض الأطبــاء

بروتوكو لات تعاون مـــا بــين المستـشفيات عن طريق إرسالهم بعثات إلى الخارج مــن قبل وز ارة الصحة وذلك بهذف التعلم.

المصرية ونظير اتها العالمية لتبادل الخبرات

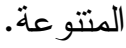

د. قدوم بعض الأطباء الأجاتب لمباثــرة ب. عمل برامج تدريبية من خـلال وزارة

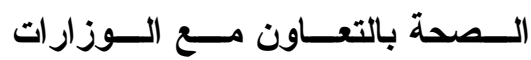

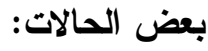
(المختلفة: تقوم وزارة الصحة بإعداد العديد من نجد أن التعدد الثقافي يبرز أيضًا فـي البر امج التدرييية لأطبائها بالتعاون مع بعض باعض لهرد

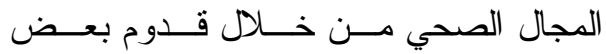
وزارات الصحة بالدول المختلفة لاكتـساب لهاب بهاب الأطباء الأجانب لمباشرة بعـض الحــالات المهار ات اللازمة للأطباء مما ينتج عنه تعدد بمصر منل مستشفى دار الفــؤاد و المركـز نقافي بين المشاركين في التدريبات. الطبي العالمي و المركز العالمي لجراحسات 
القلب مما يترتب عليه تفاعل بــين الأطبــاء متل الطبيب المصري العالمي مجدي يعقوب

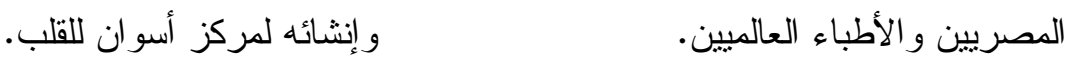
ه. بعض الأطباء سفراء لمصر بالخــارج -المجال الاجتماعي والترفيهي:

هناك العديد من أوجه التعددية التقافية ومعاونين بخبر اتهم في الا اخل: هناك بعض الأطباء المصريين الذين في المجال الاجتماعي و الترفيهي وسنوضحه

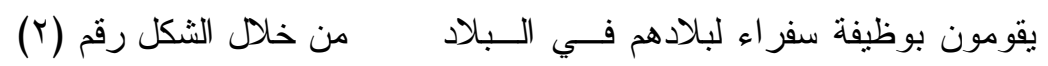

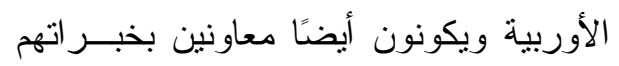

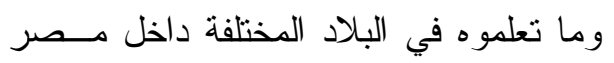

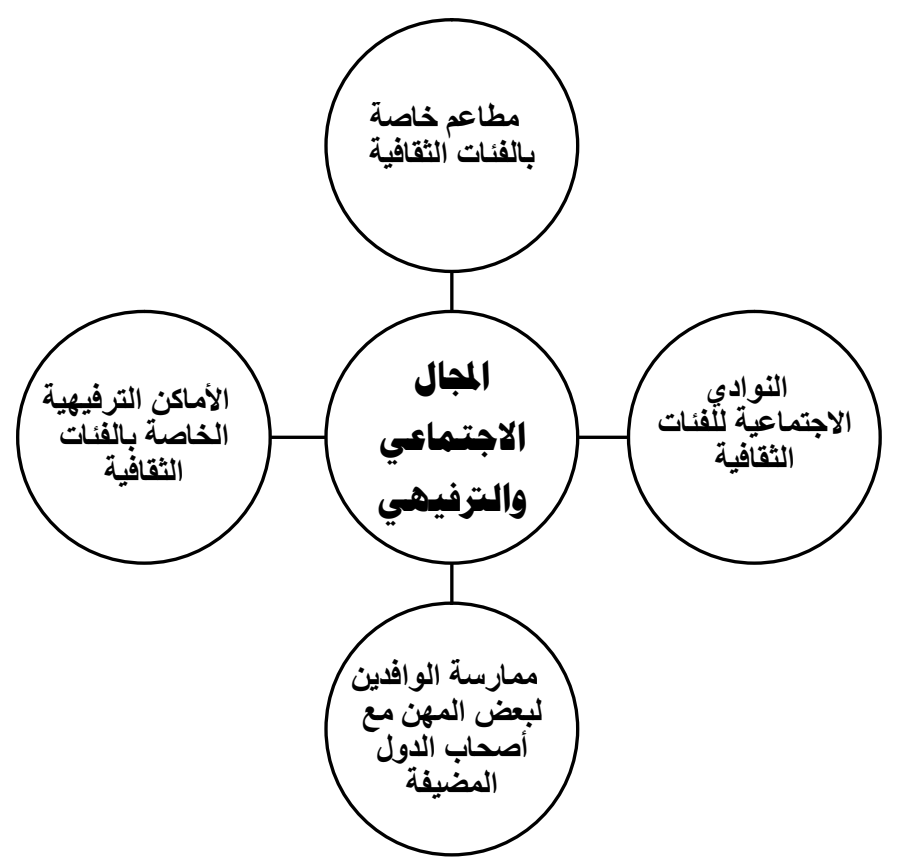

الو افدين ولكنها تقتقر في تلك المنظمات إلـى أ. النوادي الاجتماعية للفئات الثقافية:

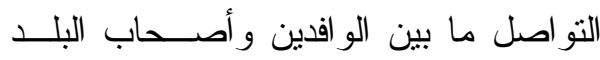
المضيفة ولكن في الجامعات تكــون بـشكل أفضل من المنظمات إلا أنها تحتاج إلى شكل فلى أكبر من التواصل ما بين الو افدين وذويهــ إلتح

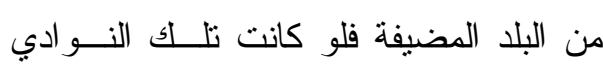
تعتبر نو ادي الطلبة الو افدين من أهـــ

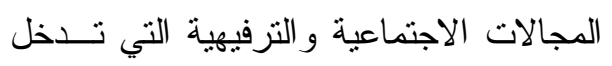

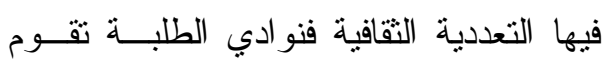

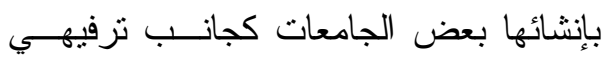

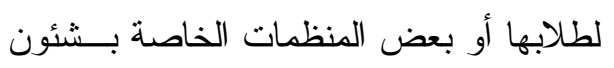


أيضًا أن الو افدين يمارسون أيضًا مهن عامة في المطاعم و الأسو اق و النو ادي و الكافيهــات

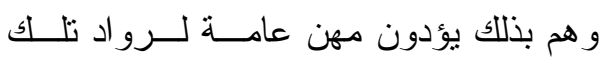

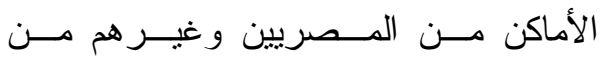

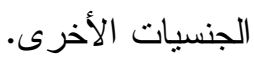

د. الأماكن الترفيهية الخاصــة بالفئـات

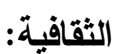

نجد أن من نماذج التعددية النقافية في مجتمعنا المصري هو انتشار سلوكيات بعض هض

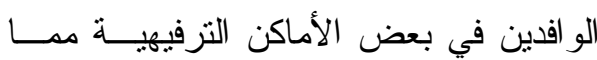

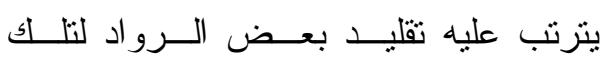

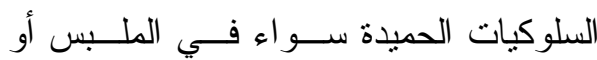
المأكل أو طريقة الكلام أو السلوكيات العامة

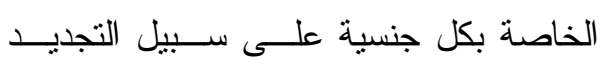

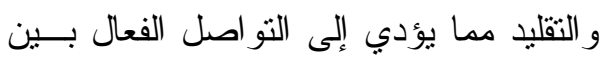
الو افدين و المصريين و العكس صحيح. r- المجال الثقافي والمعلوماتي:

هناك العديد من أوجه التعددية التقافية

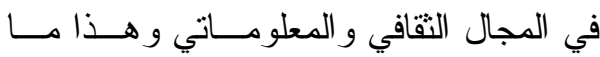
سنتتاوله بشيء من التقصيل من خله الثكل

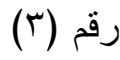

للجميع و افدين وغير و افدين لكانت فــرص التو اصل أكبر بكثير · ب. مطاعم خاصة بالفئات الثقافية: نتيجة لوجود أعداد من الو افدين فـي

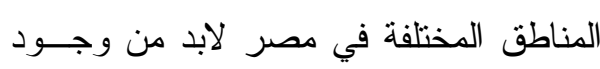
وتو افر خدمات خاصـــة بهـــؤلاء الو افــدين

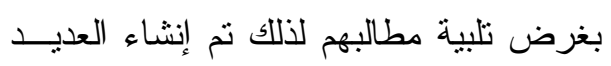

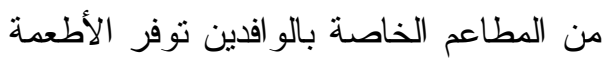

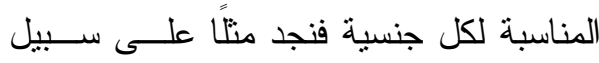
المثال المطاعم اليمنية و الصبينية والـسورية

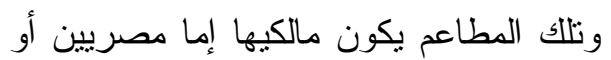

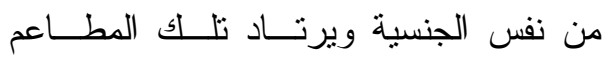
المصريين وكذلك الجنسيات الأخرى. ج. ممارســـة الوافــدين لــبعض المهــن بالاشترالك مع أصحاب البلا المضيفة:

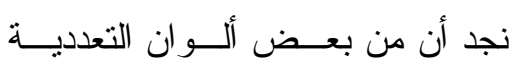

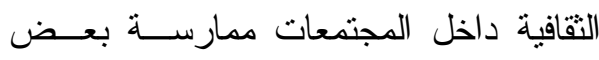

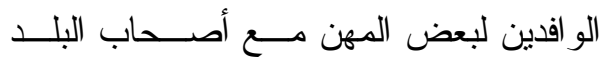

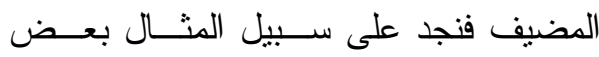
الطلاب الو افدين من كليات الطب يمارسون الطب كمساعدين للأطباء المصريين ونجـــــئ 


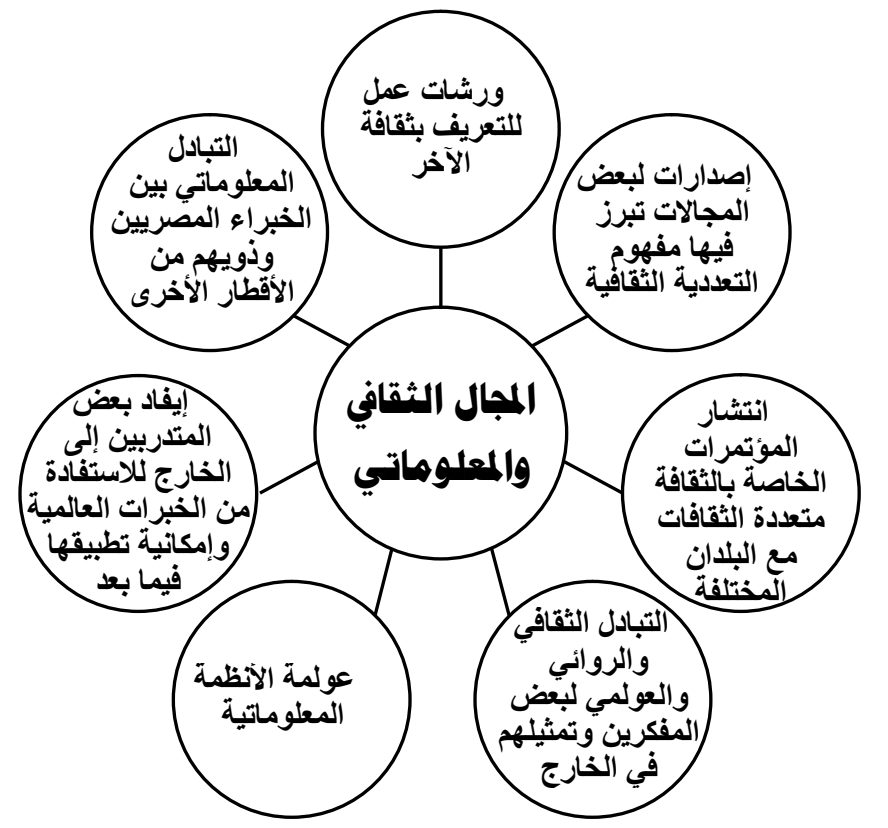

شكل (r) يوضح أوجه التعددية الثقافية في المجال الثقافي والمعلوماتي

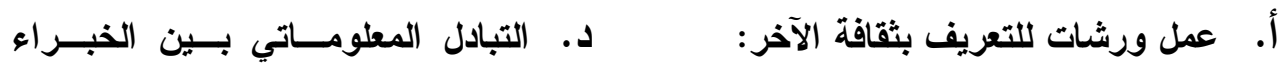

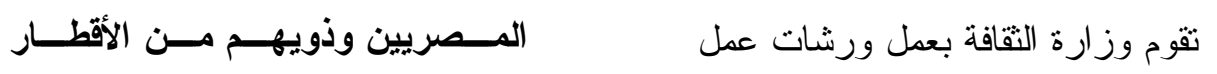

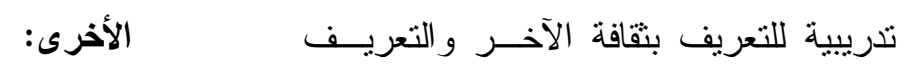

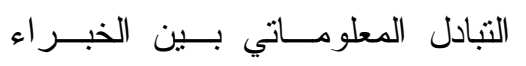

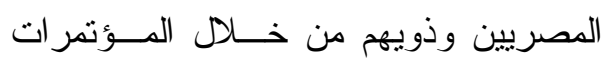

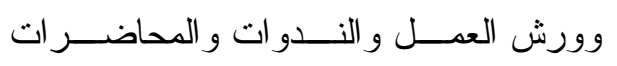

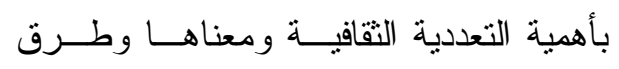

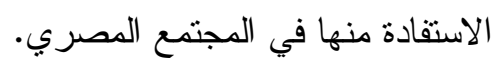

ب. عولمة الأظمة المعلوماتية:

تقوم على عولمة الأنظمة المعلوماتية الثقافية.

ه. إصدارات لبعض المجلات تبرز فيها

\section{مفهوم التعددية الثقافية:}

تقوم وزارة الثقافة بإصدار المجــلات

و الحوليات و الدوريات التابعة لها و التي تفرد

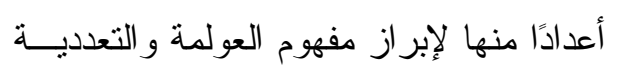

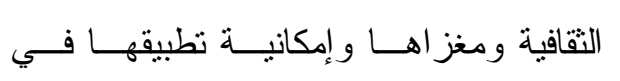

المجتمعات المختلفة.

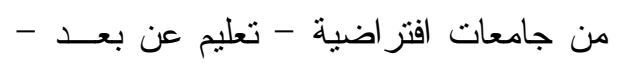
جامعات تقليدية ذات بر امج إلكترونية لتدعيم التتمية و التعددية الثقافية. ج. التبادل الثقافي للمفكرين وتمثيلهم في

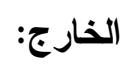

إيفاد مفكرين من خلال التبادل النقافي

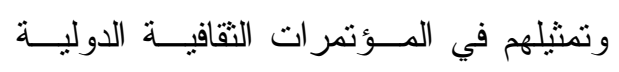
و الإقليمية. 


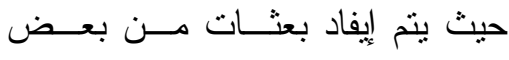

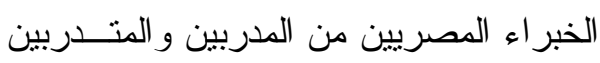

إلى الخارج للاستفادة من الخبرات العالميـــة

في المجال المعلوماتي و التقني فــي الــبلاد

الموفدون إليها ومحاولة تطبيقها فيما بعد في

بلادهم الأصلية بما يتلاعم و البيئة المصرية.

ع - المجال التعليمي والبحث العلمي:

نجد أن هناك العديد من أوجه التعددية

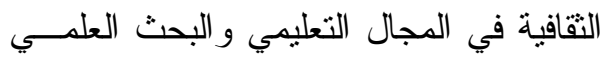

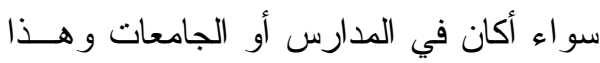

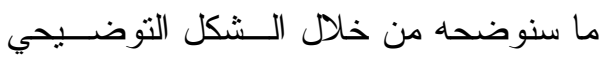

رقم (ع) مع شيء من التفصيل بعد ذللك:
و. انثتار المؤتمرات الخاصة بالثقافة

متعــدة الثقافـــات مـــع البلــــان

المختلفة:

انتشار مــؤتمر ات خاصـــة بـــوزارة

الثقافة تكون أهدافها هي التعريف بالتعدديــة

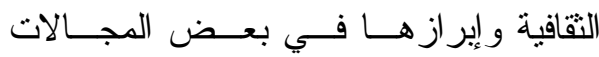
الخاصة بالثقافة وذللك بالتعاون مـــع بعـض بـ

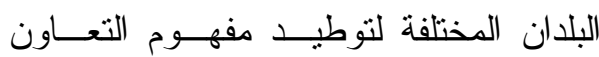
و التعدد الثقافي داخل المؤتمر ات من خــلال

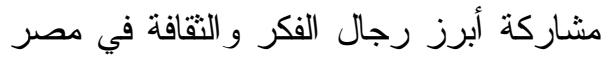

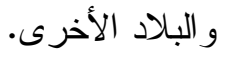

ز. ز إيفاد بعض المتلربين إلى الخـــارج

للاستفادة من الخبــرات العالميــة

و إمكانية تطبيقها فيما بعد:

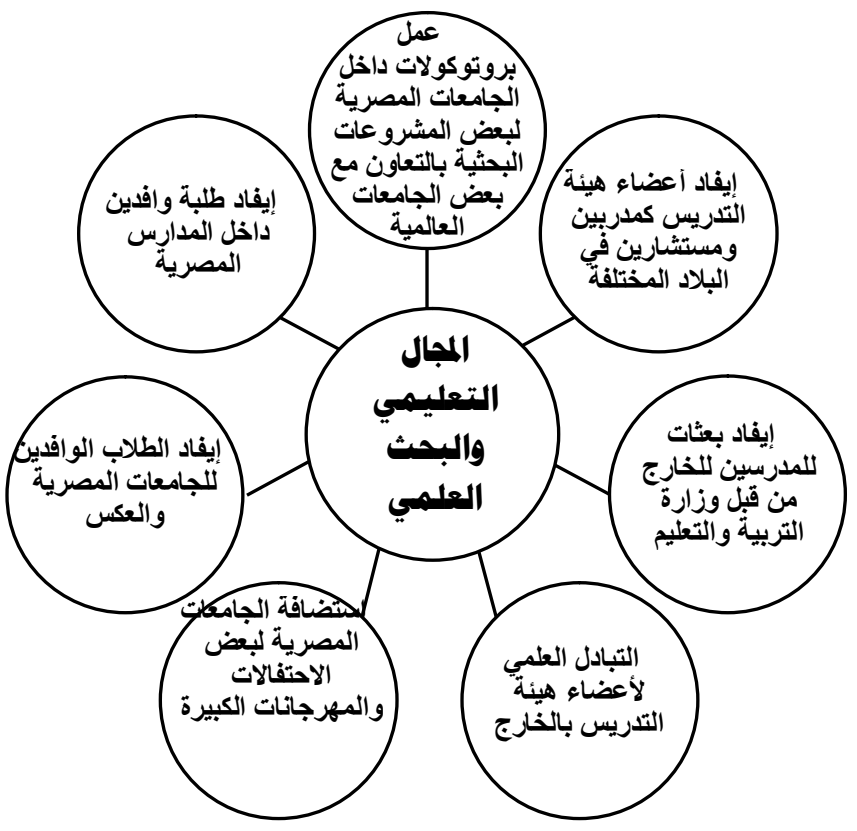

شكل (؛ ) يوضح أوجه التعدية الثقافية في المجال التعليمي والبحث العلمي 
حيث يساعد هؤلاء الأعضاء فـي نوصـيل

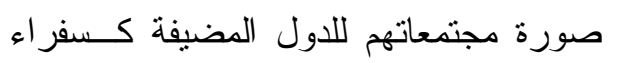

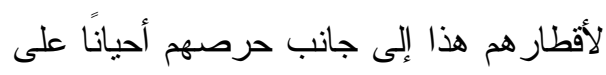

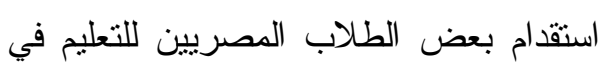

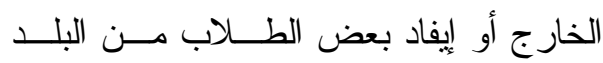
المضيف إلى مــصر فــي إطـار التعــاون

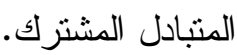

ج. إيفاد بعثات للمدرسين للخارج من قبل

$$
\text { وزارة التربية و التعليم: }
$$

نجد أن وزارة التربية و التعليم تـسعى إلى عولمة التعليم وجعله متعدد الثقافات من خلال إيفاد بعثات خاصـة بــوز ارة التربيـــة و التعليم لمدرسيها إلى بعض الدول الأوربية

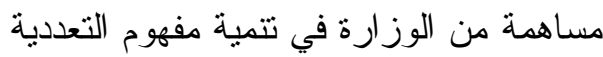
الثقافية لاى معلميها. د. التبادل العلمي لأعضاء هيئة التدريس

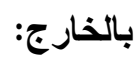

ويكون ذلك من خــلدل المــؤتمرات

و اللقاءات التي يتبادل فيهــــا أعــضـاء هيئـــة التدريس بالجامعات أعمالهم العلمية و التقافية

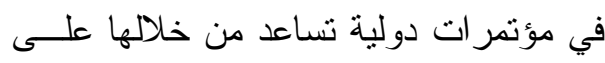
نقل الفكر و المعلومات إلى الآخر . ه. استضافة الجامعات المصرية لــبعض الاحتفالات و المهرجانات الكبيرة:

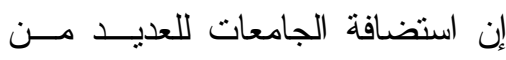

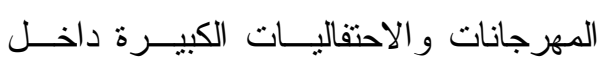

أ. عمل بروتوكولات داخـل الجامعــات المصرية لبعض المشروعات البحثيــة بالتعاون مع بعض الجامعات العالمية: إن التعددية الثقافية تدخل في المجــال

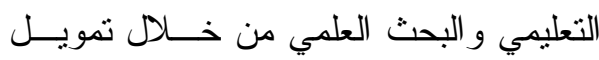
العديد من البحوث العلمية و التي تتعاون من

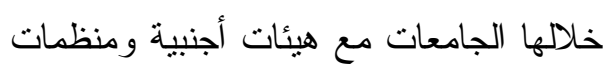
دولية في تمويل تللك الأبحاث هذا إلى جانب الاتفاقيات الثقافية حيث تـــنبط الجامعــات لـاتيل بالعديد من الاتفاقيات و البروتوكو لات الثقافية

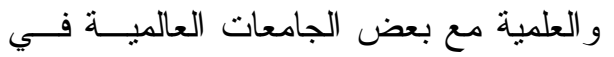
فرنسا - المجر - بلغاريا - بولندا - غانا - بعض الجعان

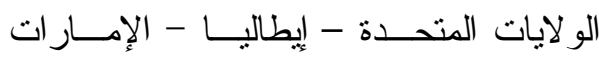

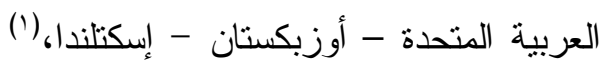
مما يسمح للتعددية الثقافية بالظهور في هــــا المجال من خلال الجوانب الثقافية والتعليمية للدول الأجنبية. ب. إيفاد بعض أعضاء هيئـة التــدريس كمدربين ومستـشارين فــي الــبلاد

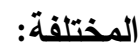

نجد أن التعددية الثقافية تبرز بـشكل

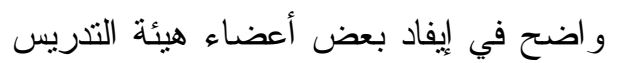
كمدربين ومستشارين في الــبلاد المختلفــة هيتة

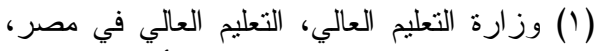

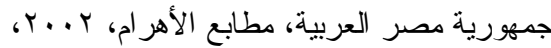


لبعض الظروف الر اهنة ببعض البلاد مثـلـ ظروف الطلاب الكويتيين إبان غزو العراق وكذلكك هذه الأيام الطلبة الــسوريين نظــــا لأوضاع أسر هم مما يتزتب عليــهـ انــدماج

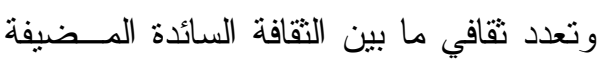
و الثقافة الو افدة.

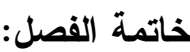

بعد أن تتاولنا التعددية الثقافية كنبــذة تاريخية وكمهوم وسياسات ومبادئ ومظاهر

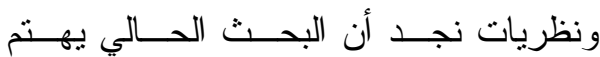
بالتعددية الثقافية بوجه عام وفي مجال التعليم و البحث العلمي بوجه خاص وما يرتبط بـــه من مظاهر ثقافية متعددة وتقع الدراسة فــي مجال التعددية النقافية و التي تز ايد الاهنمــام

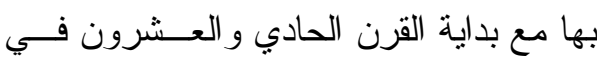

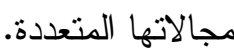

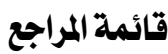

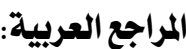

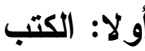

1- ايميل فهمي ، التعليم في مــصر ، دوار دار الغد العربي، القاهرة، 191V. r- عادل منصور صالح، دراسات في الفكر التزبــوي "عولمـــة التربيــة وتربية العولمة"، المكتبة التربوية، .$r .17$
أسوار الجامعة له أكبر الأثر في ظهور جلي

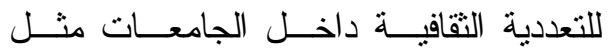
استضافة الجامعات لأسبوع شباب الجامعات

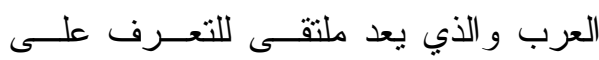

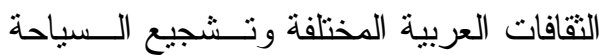
العربية وتبادل الخبــرات بـين الجامعــات العربية في الأنشطة المختلفة.(') و. إيفاد الطــلاب الوافــين للجامعــات المصرية و العكس:

تكمن التعددية الثقافية أيضًا في إيفــاد

طلاب و افدين للجامعات المصرية لاستكمال

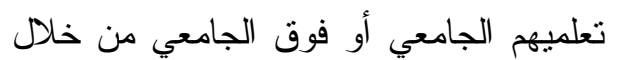

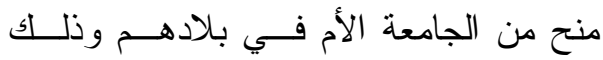

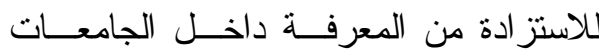

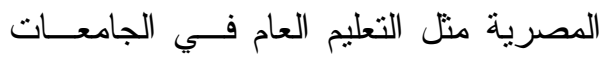
المصرية أو التعليم الديني و العام أيضًا فـي لئي جامعة الأزهر و المعاهد الأزهريـــة وكـــللك ولكي العكس دراسة المصريين كطلبة و افدين داخل

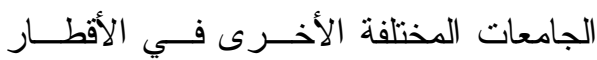
المختلفة. ز.وجود طلبة وافدين داخـلـل المـــارس

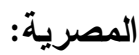
نجد أن هناك طلبة في مرحلة التعلــيم ما قبل الجامعي في المدارس المصرية نظرًا (1) جامعة المنصورة، كلية الصيدلة، دليل الطالب

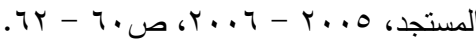




$$
\begin{aligned}
& \text { الثقافية و الثقافة السياسية العربيــة، }
\end{aligned}
$$

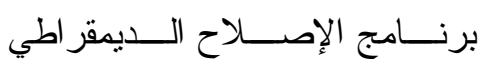

$$
\begin{aligned}
& \text { و الثقافة السياسية و التـشاركية فــي لإسي }
\end{aligned}
$$

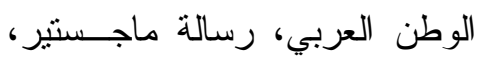

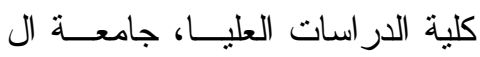

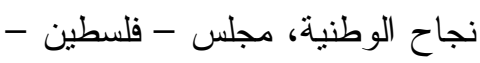

$$
\begin{aligned}
& .4 .0 \\
& \text { Y- ناهد محمد عبــد المقـصود عبـد } \\
& \text { الرازق، التعددية الثقافية و التعلــيم } \\
& \text { و انعكاساتها على طلاب المــدارس } \\
& \text { الأجنبيــة فــي مــصر ، رســالة } \\
& \text { ماجستير ، كلية التربيــة، جامعــة }
\end{aligned}
$$

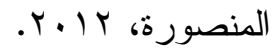

$$
\begin{aligned}
& \text { رابعا: النشرات و الوثائق } \\
& \text { 1 - وزارة التعليم العالي، التعليم العالي }
\end{aligned}
$$

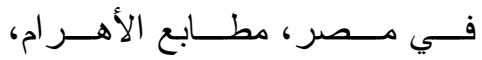

$$
\begin{aligned}
& \text { جمهورية مصر العربية، r...... }
\end{aligned}
$$

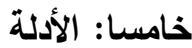

$$
\begin{aligned}
& 1 \text { - جامعة المنصورة، كلية الــصيلة } \\
& \text { "دليل الطالب المسستجد"، 0. . ب ـ ـ } \\
& . r . . T \\
& \text { سادسا: المعاجم والموسوعات } \\
& 1 \text { - سليم حسن، موسوعة مصر القديمة }
\end{aligned}
$$

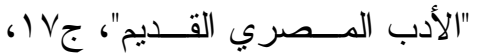

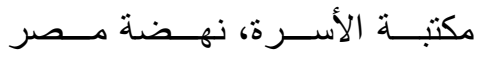

$$
\begin{aligned}
& \text { للطباعة و النشر ، القاهرة، .... ب. }
\end{aligned}
$$

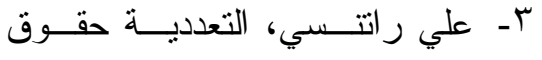

$$
\begin{aligned}
& \text { قصيرة جدًا، ترجمة لبنـى عمـــاد } \\
& \text { تركي، طا ، مؤسسة هنداوي للتعليم } \\
& \text { و الثقافة، القاهرة، 11 بـ بـ. } \\
& \text { عـ - محمد سعد عبد الحميــد، الجامعــة }
\end{aligned}
$$

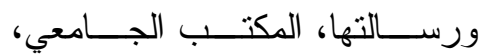

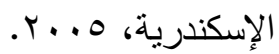

$$
\begin{aligned}
& \text { 0ـ ويل ديورانت، قـــة الحــضارة }
\end{aligned}
$$

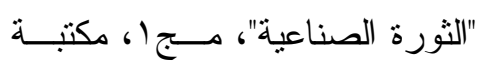

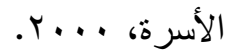

$$
\begin{aligned}
& \text { ثانيا: الدوريات } \\
& . Y \cdot 11
\end{aligned}
$$


press, 1971.

5- R.

Hosan,

Multiculturalism; some in convenient truths, politico press, 2010.

6- Schon waldee, integration policy \& pluralism in a self-conscious country of migration, Rutledge, Germany, 2010.

7- W. Kymlicka, multicultural citizenship, A liberal theory of minority right, Oxford university press, 1995.

8- Y. Ali elbahi-Brown, After multicultural, foreign policy centers, 2000.

\section{2- Newspapers articles:}

1- R. Dly, My life as nudes cover rue-lim, the guardian, 15 February, 2010.

\section{3- Internet:}

1- http://ar.farhangaelm.com,2 012.

2- http://www.hindaui.org/kal emat.2012.

3- http://www.wikipedia.org.2 012.

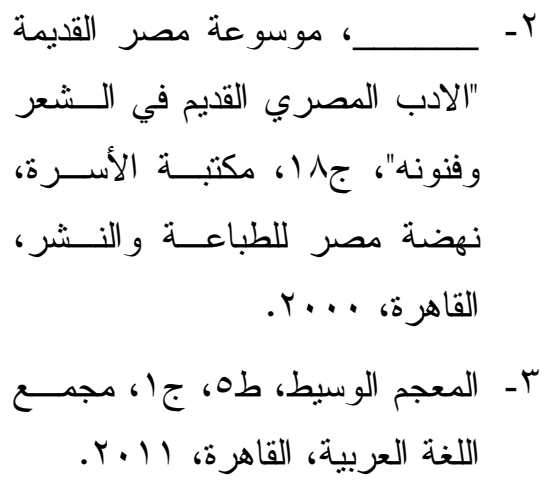

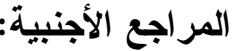

\section{1- Books:}

1- B. Barry, culture \& equality: An egalitarian critique of multiculturalism, polity press, 2001.

2sociologists, economists and democracy, university of Chicago press, 1988.

3- C. Taylor, the politico of recognition. In A. Guttmann (ed) multiculturalism and the polities of recognition, Princeton university press, 1944.

4- John Rawls, A theory of justice, Harvard university 